\title{
Effectiveness of enhanced external counter pulsation on clinical profile and health-related quality of life in patients with coronary heart disease: a systematic review
}

\author{
Vikram Singh ${ }^{1,2}$, Girija Kumari', ${ }^{1,}$ Bimal Chhajer², Ashok Kumar Jhingan ${ }^{3}$, Saurabh Dahiya' \\ 'Lingaya's University, Nachauli, Jasana Road, Old Faridabad, Faridabad, India \\ ${ }^{2}$ SAAOL Heart Center, Chhatarpur, New Delhi, India \\ ${ }^{3}$ Delhi Diabetes Research Center, New Delhi, India
}

\begin{abstract}
Introduction. Enhanced External Counter Pulsation (EECP) is a non-invasive United States Food and Drug Administration (FDA) approved outpatient treatment option for the complex problem of angina, a common symptom of coronary heart disease. A systematic review of the literature searched to assess the effect of EECP on the clinical profile that comprised physiological measurements, biochemical assessments, cardiac clinical symptoms, physical functional status, and Health-Related Quality of Life (HRQoL) in Coronary Heart Disease (CHD) patients.
\end{abstract}

Material and methods. Total 258 EECP research articles from the early stage of EECP development to till date screened. Out of 258 EECP articles, total 60 articles (53 EECP articles for clinical profile and 7 article for $H R Q o L$ matched the inclusion criteria and other $(n=198)$ articles excluded due to irrelevant to study objectives. Results. All enrolled studies showed a significant improvement in angina pectoris and HRQoL with reduction of nitroglycerine use and exercise tolerance. There are several gaps in research has been found for further research to evaluate the EECP effectiveness on Body Mass Index (BMI), Heart Rate, Cholesterol, Triglyceride, High Density Lipoprotein (HDL), Low Density Lipoprotein (LDL), HbA IC, $\mathrm{SpO}_{2}$, Vo $\mathrm{v}_{2}$ max level with a comparative assessment of cardiac and non-cardiac metabolic markers including blood glucose.

Conclusions. There is further need of multi-centric randomize controlled trial studies to evaluate the effect of EECP on obese, diabetic, hypertension and other metabolic disease patients and more research required for further modifications in EECP device to cure, prevent and treat chronic diseases by the non-invasive procedure.

Key words: enhanced external counter pulsation, angina pectoris, health-related quality of life,coronary heart disease

Acta Angiol 2018; 24, 4: 105-122

\section{Introduction}

Cardiovascular disease, especially Coronary Heart disease $(\mathrm{CHD})$ is the number one killer and foremost cause of deaths around the world [I]. Angina pectoris, the prime symptom of coronary heart disease ranked first among causes of mortality [2]. The current non-pharmacological and non-invasive therapy available

Address for correspondence: Saurabh Dahiya, Lingaya's University, Nachauli, Jasana Road, Old Faridabad, Faridabad, Haryana, I21002 Faridabad, Indie, e-mail: saurabhdahiya@gmail.com 
for chronic stable angina (a typical symptom of coronary heart disease) and heart failure is Enhanced External Counter Pulsation (EECP). EECP is USA-FDA approved therapy for coronary heart disease patient [3].

EECP, an electro-mechanical system is a registered trademark of Vasomedical, Inc, New York, USA and PSK (Chinese Company) is the exclusive distributor of Vasomedical'sdevices all over the world [4-8]. CHD patients usually undergo EECP treatment of 35 consecutive I-hour sessions over 5-7 weeks. Treatment patient is continuously monitored for cardiac outputs, heart rate and spo2 using ECG and finger plethysmogram, which are connected to the EECP device [9-II]. This study designed to evaluate the effect of EECP in Clinical profile and HRQoL in CHD patients.

\section{Material and methods}

\section{Searching methods}

A systemic review of the literature of EECP on clinical profile and HRQoL in coronary heart disease patients was search through PubMed, Medline, Vasomedical EECP manufacturer web-link, and Google scholar sources. Searching for the articles done as per the inclusion and exclusion criteria of the study and the studies summarized in Figure I.

\section{Inclusion criteria}

EECP article of Randomized Control Trial (RCT), case studies, prospective and retrospective studies on clinical profile and HRQoL in coronary heart disease patients were included.

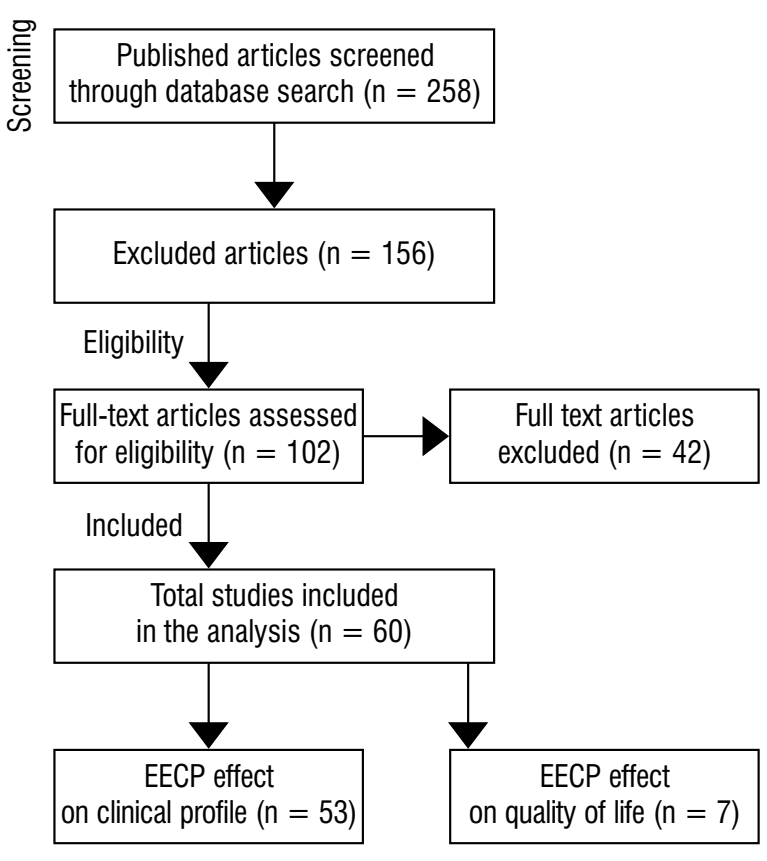

Figure I. Flowchart of screened and included studies

\section{Exclusion criteria}

Heart Failure studies, Non-cardiac EECP studies with RCT, Case studies, Prospective and Retrospective and reviews of EECP papers excluded from the study.

\section{Quality assessment}

Study quality was assessed through two authors independently. Newcastle-Ottawa scale (NOS) was used to assess the quality of studies. Detail of assessment is given in Tables I, 2.

Table I. Newcastle-Ottawa scale in the assessment of clinical profile included studies

\begin{tabular}{|c|c|c|c|c|c|c|c|c|c|}
\hline Study & $\begin{array}{l}\text { Is the } \\
\text { case de- } \\
\text { finition } \\
\text { ade- } \\
\text { quate? } \\
\text { (one } \\
\text { point) }\end{array}$ & $\begin{array}{l}\text { Repre- } \\
\text { sentati- } \\
\text { veness } \\
\text { of } \\
\text { cases } \\
\text { (one } \\
\text { point) }\end{array}$ & $\begin{array}{l}\text { Selec- } \\
\text { tion of } \\
\text { controls } \\
\text { (one } \\
\text { point) }\end{array}$ & $\begin{array}{l}\text { Defini- } \\
\text { tion of } \\
\text { controls } \\
\text { (one } \\
\text { point) }\end{array}$ & $\begin{array}{l}\text { As- } \\
\text { sessment } \\
\text { of outco- } \\
\text { me (one } \\
\text { point) }\end{array}$ & $\begin{array}{l}\text { Ade- } \\
\text { quacy of } \\
\text { cohort } \\
\text { follow- } \\
\text {-up (one } \\
\text { point) }\end{array}$ & $\begin{array}{l}\text { Was } \\
\text { follow- } \\
\text {-up long } \\
\text { enough for } \\
\text { outcomes } \\
\text { to occur? } \\
\text { (one point) }\end{array}$ & $\begin{array}{l}\text { Comparabi- } \\
\text { lity of cases } \\
\text { and controls } \\
\text { on basis of } \\
\text { design } \\
\text { or analysis } \\
\text { (two points) }\end{array}$ & $\begin{array}{c}\text { Total } \\
\text { score } \\
\text { (nine } \\
\text { points) }\end{array}$ \\
\hline Lawson et al. 1992 & 1 & I & $\mathrm{I}$ & I & $\mathrm{I}$ & I & I & 2 & 9 \\
\hline Sjukri et al. 1995 & I & I & I & I & I & I & I & 2 & 9 \\
\hline Arora et al. 1999 & I & I & 1 & 1 & I & I & I & 2 & 9 \\
\hline Lawson et al. 2000 & I & I & 1 & I & I & I & I & 2 & 9 \\
\hline Lawson et al. 2000 & $\mathrm{I}$ & $\mathrm{I}$ & 1 & 1 & 1 & I & 1 & 2 & 9 \\
\hline Urano et al. 200I & $\mathrm{I}$ & I & $\mathrm{I}$ & $\mathrm{I}$ & $\mathrm{I}$ & $\mathrm{I}$ & $\mathrm{I}$ & 2 & 9 \\
\hline Stys et al. 200I & I & 1 & 1 & 1 & $\mathrm{I}$ & I & 1 & 2 & 9 \\
\hline Barsness et al. 200I & 1 & 1 & $\mathrm{I}$ & $\mathrm{I}$ & $\mathrm{I}$ & 1 & $\mathrm{I}$ & 2 & 9 \\
\hline Springer S et al. 200 I & 1 & 1 & $\mathrm{I}$ & $\mathrm{I}$ & I & 1 & 1 & 2 & 9 \\
\hline Lakshmi et al. 2002 & 1 & 1 & $\mathrm{I}$ & 1 & 1 & 1 & 1 & 2 & 9 \\
\hline Stys et al. 2002 & I & 1 & I & 1 & I & 1 & I & 2 & 9 \\
\hline Michaels et al. 2002 & I & I & I & I & I & I & 0 & 2 & 8 \\
\hline
\end{tabular}


Table I. cont. Newcastle-Ottawa scale in the assessment of clinical profile included studies

\begin{tabular}{|c|c|c|c|c|c|c|c|c|c|}
\hline Study & $\begin{array}{l}\text { Is the } \\
\text { case de- } \\
\text { finition } \\
\text { ade- } \\
\text { quate? } \\
\text { (one } \\
\text { point) }\end{array}$ & $\begin{array}{l}\text { Repre- } \\
\text { sentati- } \\
\text { veness } \\
\text { of } \\
\text { cases } \\
\text { (one } \\
\text { point) }\end{array}$ & $\begin{array}{l}\text { Selec- } \\
\text { tion of } \\
\text { controls } \\
\text { (one } \\
\text { point) }\end{array}$ & $\begin{array}{l}\text { Defini- } \\
\text { tion of } \\
\text { controls } \\
\text { (one } \\
\text { point) }\end{array}$ & $\begin{array}{l}\text { As- } \\
\text { sessment } \\
\text { of outco- } \\
\text { me (one } \\
\text { point) }\end{array}$ & $\begin{array}{l}\text { Ade- } \\
\text { quacy of } \\
\text { cohort } \\
\text { follow- } \\
\text {-up (one } \\
\text { point) }\end{array}$ & $\begin{array}{l}\text { Was } \\
\text { follow- } \\
\text {-up long } \\
\text { enough for } \\
\text { outcomes } \\
\text { to occur? } \\
\text { (one point) }\end{array}$ & $\begin{array}{l}\text { Comparabi- } \\
\text { lity of cases } \\
\text { and controls } \\
\text { on basis of } \\
\text { design } \\
\text { or analysis } \\
\text { (two points) }\end{array}$ & $\begin{array}{l}\text { Total } \\
\text { score } \\
\text { (nine } \\
\text { points) }\end{array}$ \\
\hline Soran et al. 2002 & I & I & I & I & 1 & I & I & 2 & 9 \\
\hline Fitzgerald et al. 2003 & 1 & $\mathrm{I}$ & $\mathrm{I}$ & $\mathrm{I}$ & 1 & 1 & $\mathrm{I}$ & 2 & 9 \\
\hline Bonetti et al. 2003 & 1 & I & $\mathrm{I}$ & 1 & 1 & $\mathrm{I}$ & 1 & 2 & 9 \\
\hline Schecter et al. 2003 & I & I & 1 & I & 1 & 1 & I & 2 & 9 \\
\hline Tartaglia et al. 2003 & I & 1 & 1 & $\mathrm{I}$ & 1 & $\mathrm{I}$ & $I$ & 2 & 9 \\
\hline Werner et al. 2003 & 1 & 1 & 1 & 1 & 1 & $\mathrm{I}$ & $\mathrm{I}$ & 2 & 9 \\
\hline Lawson et al. 2003 & 1 & 1 & 1 & $\mathrm{I}$ & 1 & 1 & 1 & 2 & 9 \\
\hline Linnemeier et al. 2003 & 1 & 1 & 1 & $\mathrm{I}$ & 1 & I & I & 2 & 9 \\
\hline Linnemeier et al. 2003 & 1 & 1 & I & I & 1 & I & I & 2 & 9 \\
\hline Bagger et al. 2004 & 1 & 1 & 1 & $\mathrm{I}$ & 1 & $\mathrm{I}$ & 0 & 2 & 8 \\
\hline Michaels et al. 2004 & 1 & $\mathrm{I}$ & $\mathrm{I}$ & $\mathrm{I}$ & $\mathrm{I}$ & $\mathrm{I}$ & $\mathrm{I}$ & 2 & 9 \\
\hline Lawson et al. 2004 & $\mathrm{I}$ & $\mathrm{I}$ & $\mathrm{I}$ & $\mathrm{I}$ & $\mathrm{I}$ & $\mathrm{I}$ & $\mathrm{I}$ & 2 & 9 \\
\hline Masuda et al. 2004 & $\mathrm{I}$ & $\mathrm{I}$ & $\mathrm{I}$ & $\mathrm{I}$ & $\mathrm{I}$ & $\mathrm{I}$ & $\mathrm{I}$ & 2 & 9 \\
\hline Henrikson et al. 2004 & 1 & 1 & 1 & 1 & $\mathrm{I}$ & $\mathrm{I}$ & $\mathrm{I}$ & 2 & 9 \\
\hline Taguchi et al. 2004 & $\mathrm{I}$ & I & 1 & 1 & 1 & $\mathrm{I}$ & 1 & 2 & 9 \\
\hline Lawson et al. 2005 & 1 & I & I & 1 & 1 & I & 1 & 2 & 9 \\
\hline Michaels et al. 2005 & 1 & 1 & 1 & 1 & 1 & $\mathrm{I}$ & 1 & 2 & 9 \\
\hline Arora et al. 2005 & 1 & $\mathrm{I}$ & 1 & 1 & $\mathrm{I}$ & 1 & 1 & 2 & 9 \\
\hline McCullough et al. 2006 & 1 & 1 & 1 & 1 & $\mathrm{I}$ & 1 & $\mathrm{I}$ & 2 & 9 \\
\hline Soran et al. 2006 & $\mathrm{I}$ & $\mathrm{I}$ & $\mathrm{I}$ & $\mathrm{I}$ & $\mathrm{I}$ & $\mathrm{I}$ & $\mathrm{I}$ & 2 & 9 \\
\hline Akhtar et al. 2006 & I & I & 1 & I & I & I & $\mathrm{I}$ & 2 & 9 \\
\hline Nichols et al. 2006 & $\mathrm{I}$ & $\mathrm{I}$ & 1 & 1 & $\mathrm{I}$ & $\mathrm{I}$ & 1 & 2 & 9 \\
\hline Lawson et al. 2006 & $\mathrm{I}$ & $\mathrm{I}$ & $\mathrm{I}$ & $\mathrm{I}$ & $\mathrm{I}$ & $\mathrm{I}$ & $\mathrm{I}$ & 2 & 9 \\
\hline Novo et al. 2006 & $\mathrm{I}$ & 1 & 1 & 1 & 1 & 1 & $\mathrm{I}$ & 2 & 9 \\
\hline Loh et al. 2006 & $\mathrm{I}$ & 1 & 1 & 1 & 1 & $\mathrm{I}$ & 1 & 2 & 9 \\
\hline Arora et al. 2007 & $\mathrm{I}$ & 1 & 1 & 1 & $\mathrm{I}$ & $\mathrm{I}$ & $\mathrm{I}$ & 2 & 9 \\
\hline Michaels et al. 2007 & $\mathrm{I}$ & $\mathrm{I}$ & $\mathrm{I}$ & 1 & $\mathrm{I}$ & $\mathrm{I}$ & $\mathrm{I}$ & 2 & 9 \\
\hline McCullough et al. 2007 & $\mathrm{I}$ & 1 & 1 & 1 & 1 & 1 & 1 & 2 & 9 \\
\hline Yavari et al. 2007 & 1 & 1 & $\mathrm{I}$ & $\mathrm{I}$ & 1 & 1 & 1 & 2 & 9 \\
\hline Loh et al. 2008 & $\mathrm{I}$ & $\mathrm{I}$ & 1 & 1 & 1 & $\mathrm{I}$ & $\mathrm{I}$ & 2 & 9 \\
\hline Erdling et al. 2008 & 1 & 1 & 1 & 1 & 1 & 1 & 1 & 2 & 9 \\
\hline Buschmann et al. 2009 & I & I & 1 & I & 1 & 1 & I & 2 & 9 \\
\hline Esmaeilzadeh et al. 2009 & 1 & 1 & $\mathrm{I}$ & $\mathrm{I}$ & 1 & $\mathrm{I}$ & 1 & 2 & 9 \\
\hline Soran et al. 2012 & $\mathrm{I}$ & $\mathrm{I}$ & $\mathrm{I}$ & $\mathrm{I}$ & $\mathrm{I}$ & $\mathrm{I}$ & 1 & 2 & 9 \\
\hline Eslamian et al. 2013 & $\mathrm{I}$ & $\mathrm{I}$ & 1 & $\mathrm{I}$ & $\mathrm{I}$ & $\mathrm{I}$ & 1 & 2 & 9 \\
\hline Bozorgi et al. 2014 & 1 & 1 & 1 & $\mathrm{I}$ & 1 & 1 & 1 & 2 & 9 \\
\hline Beck et al. 2014 & 1 & $\mathrm{I}$ & $\mathrm{I}$ & $\mathrm{I}$ & $\mathrm{I}$ & 1 & 1 & 2 & 9 \\
\hline Tabary et al. 2015 & I & I & $\mathrm{I}$ & 1 & I & 1 & 1 & 2 & 9 \\
\hline Subramanian et al. 2016 & 1 & 1 & 1 & 1 & 1 & 1 & 0 & 2 & 8 \\
\hline Beck et al. 2016 & I & 1 & I & 1 & I & 1 & 1 & 2 & 9 \\
\hline
\end{tabular}


Table 2. Newcastle-Ottawa scale health related quality assessment of included studies

\begin{tabular}{|c|c|c|c|c|c|c|c|c|c|}
\hline Study & $\begin{array}{l}\text { Is the } \\
\text { case de- } \\
\text { finition } \\
\text { ade- } \\
\text { quate? } \\
\text { (one } \\
\text { point) }\end{array}$ & $\begin{array}{l}\text { Repre- } \\
\text { sentati- } \\
\text { veness } \\
\text { of } \\
\text { cases } \\
\text { (one } \\
\text { point) }\end{array}$ & $\begin{array}{l}\text { Selec- } \\
\text { tion of } \\
\text { controls } \\
\text { (one } \\
\text { point) }\end{array}$ & $\begin{array}{l}\text { Defini- } \\
\text { tion of } \\
\text { controls } \\
\text { (one } \\
\text { point) }\end{array}$ & $\begin{array}{l}\text { As- } \\
\text { sessment } \\
\text { of outco- } \\
\text { me (one } \\
\text { point) }\end{array}$ & $\begin{array}{l}\text { Ade- } \\
\text { quacy of } \\
\text { cohort } \\
\text { follow- } \\
\text {-up (one } \\
\text { point) }\end{array}$ & $\begin{array}{l}\text { Was } \\
\text { follow- } \\
\text {-up long } \\
\text { enough for } \\
\text { outcomes } \\
\text { to occur? } \\
\text { (one point) }\end{array}$ & $\begin{array}{l}\text { Comparabi- } \\
\text { lity of cases } \\
\text { and controls } \\
\text { on basis of } \\
\text { design } \\
\text { or analysis } \\
\text { (two points) }\end{array}$ & $\begin{array}{l}\text { Total } \\
\text { score } \\
\text { (nine } \\
\text { points) }\end{array}$ \\
\hline Arora et al. 2002 & $\mathrm{I}$ & I & 1 & I & $\mathrm{I}$ & 1 & $\mathrm{I}$ & 2 & 9 \\
\hline Kumar et al. 2009 & 1 & I & 1 & I & I & I & I & 2 & 9 \\
\hline Wu et al. 2012 & I & I & 1 & I & I & I & 0 & 2 & 8 \\
\hline Ziaeirad et al. 2012 & $\mathrm{I}$ & 1 & 1 & $\mathrm{I}$ & $\mathrm{I}$ & 1 & 1 & 2 & 9 \\
\hline Jorgensen et al. 2013 & I & 1 & 1 & 1 & 1 & $\mathrm{I}$ & $\mathrm{I}$ & 2 & 9 \\
\hline May et al. 2015 & I & 1 & 1 & $\mathrm{I}$ & 1 & 1 & 0 & 2 & 8 \\
\hline Shakouri 2015 & $\mathrm{I}$ & 1 & 1 & 1 & I & $\mathrm{I}$ & 1 & 2 & 9 \\
\hline
\end{tabular}

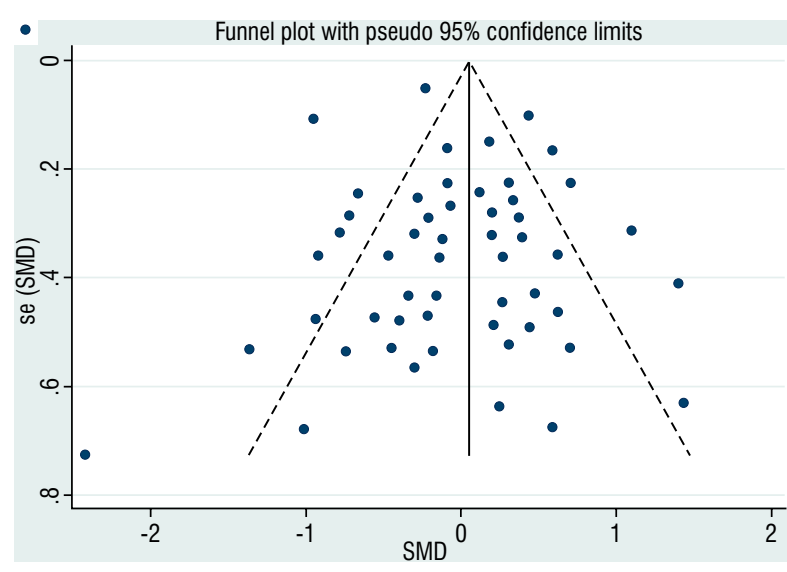

Figure 2. Funnel plot of included studies in clinical profile EECP

\section{Statistical analysis}

Statistical analyses were performed using RevMan 5.0 (Cochrane Collaboration). A random-effects model was used with weighted mean difference (WMD) in clinical profile and HRQol from pre-EECP to post-EECP. Bias in studies was assessed through visual inspection of the funnel plot as well as Begg's and Egger's testing. Detail of analysis is given in Figures 2 to 5 .

\section{EFFECT OF EECP ON CLINICAL PROFILE IN CORONARY HEART DISEASE PATIENTS}

Lawson et al. [12] conducted a study on 18 patients with chronic angina treated with an improved system of enhanced external counter pulsation (EECP) and found that all patients improved in angina symptoms and generally decreased anti-angina medications. A decrease in myocardial ischemia observed in $67 \%$ patients and $89 \%$ of patients were symptom-free. Sjukri et al. [13] carried out a study on 201 coronary heart disease

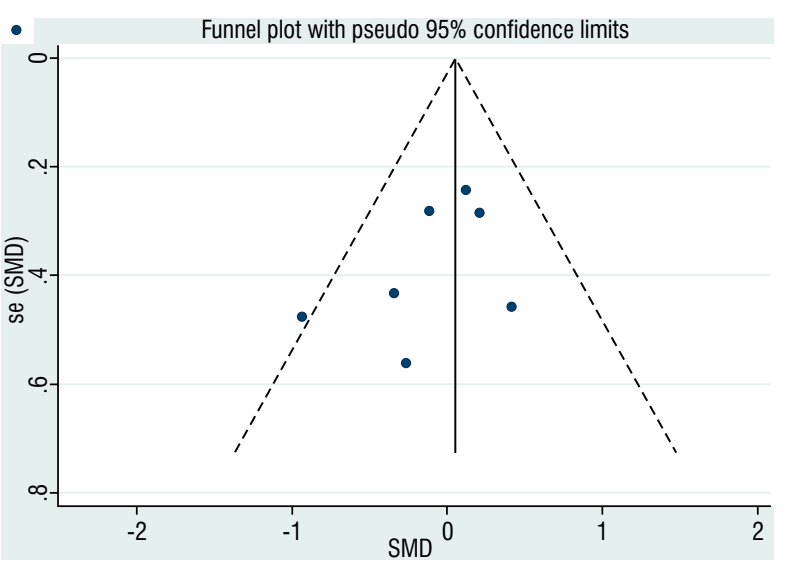

Figure 3. Funnel plot of included studies in HRQoL - EECP

patients. The results of the study showed significant improvement in coronary perfusion by $86.8 \%$ and exercise tolerance by $94.2 \%$. Arora et al. [14] performed a multi centric prospective randomized control study to assess the safety and efficacy of enhanced external counterpulsation (EECP). A significant improvement in angina severity and exercise tolerance and timing was reported. EECP showed well tolerated and safe therapy for CHD patients. Lawson et al. [ I5] carried out a study on 33 patients to evaluate the effect of EECP on longterm prognosis in CHD patients. The study suggests that particularly for the majority of patients demonstrating improvement by $64 \%$ in radionuclide stress perfusion post-treatment and EECP may be an effective long-term therapy. Lawson et al. [16] conducted a cohort study in 2,289 CHD patients to evaluate EECP safety and efficacy. EECP was found to be safe and well-tolerated therapy with improvement in angina class by $74 \%$ with significant $p$-value $(p<0.00 \mathrm{I})$. Urano et al. [17] performed a study on 5 I 2 CHD patients to examined EECP efficacy in myocardial ischemia, exercise tolerance and cardiac 
Study

Lawson et al. 1992 Sjukri et al. 1995 Arora et al. 1999 Lawson et al. 2000 Lawson et al. 2000 Urano et al. 2001

Stys et al. 2001 Barsness et al. 2001 Springer S et al. 2001 Lakshmi et al. 2002

Stys et al. 2002 Michaels et al. 2002 Soran et al. 2002 Fitzgerald et al. 2003 Bonetti et al. 2003 Schecter et al. 2003 Tartaglia et al. 2003 Werner et al. 2003 Lawson et al. 2003 Linnemeier et al. 2003 Linnemeier et al. 2003 Bagger et al. 2004 Michaels et al. 2004 Lawson et al. 2004 Masuda et al. 2004 Henrikson et al. 2004 Taguchi et al. 2004 Lawson et al. 2005 Michaels et al. 2005 Arora et al. 2005 McCullough et al. 2006 Soran et al. 2006 Akhtar et al. 2006 Nichols et al. 2006 Lawson et al. 2006 Novo et al. 2006 Loh et al. 2006 Arora et al. 2007 Michaels et al. 2007 McCullough et al. 2007 Yavari et al. 2007 Loh et al. 2008 Erdling et al. 2008 Buschmann et al. 2009 Esmaeilzadeh et al. 2009 Soran et al. 2012

Eslamian et al. 2013 Bozorgi et al. 2014 Beck et al. 2014 Tabary et al. 2015 Subramanian et al. 2016 Beck et al. 2016 Overall $(p<0.0001)$

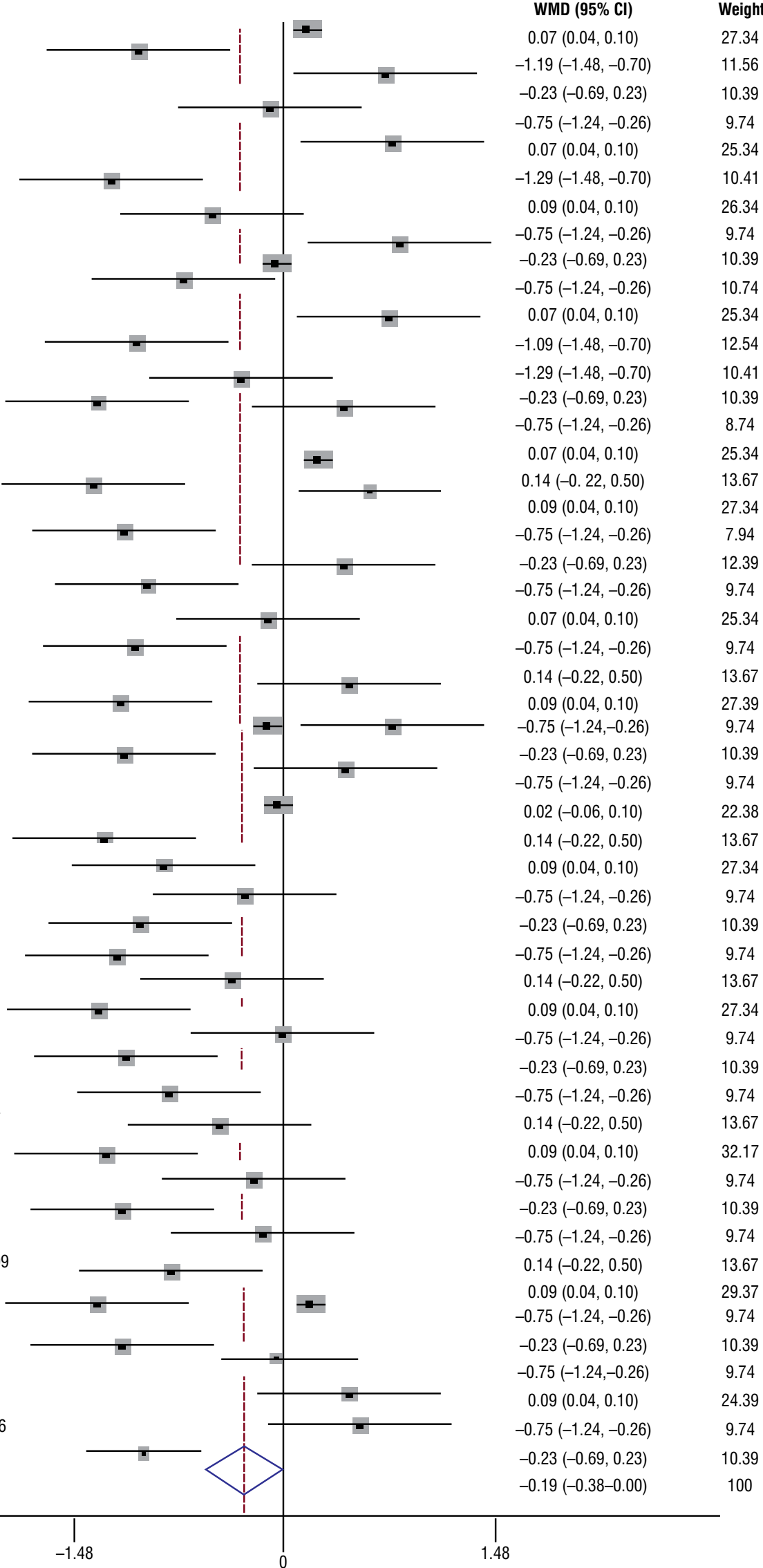

Weight

27.34

11.56

10.39

9.74

5.34

9.74

10.39

0.74

25.34

12.54

8.74

7.94

12.39

9.74

25.34

9.74

13.67

7.39

9.74

22.38

13.67

27.34

9.74

10.39

9.74

3.67

27.34

9.74

10.39

9.74

3.67

2.17

74

Figure 4. Forest plot of weighted mean differences in clinical profile in pre- and post-EECP 


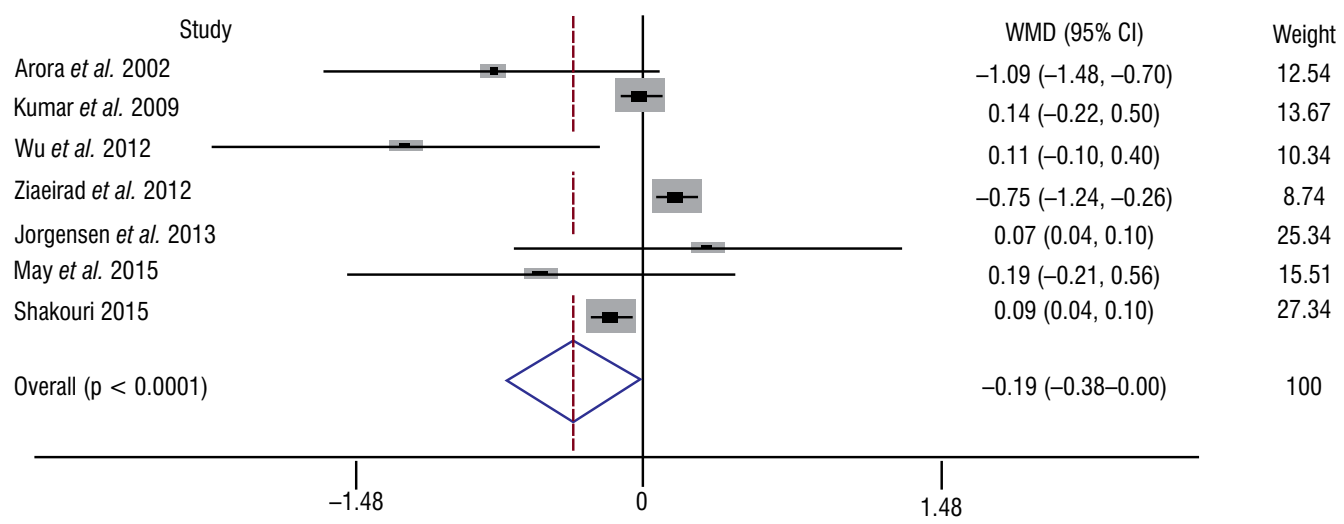

Figure 5. Forest plot of weighted mean differences in HRQoL in pre- and post-EECP

function. The result of the study reveals the improvement in exercise test parameters reduced myocardial ischemia by thallium scintigraphy in association with improved LV diastolic filling in patients with stable CAD. Stys et al. [18] carried out a clinical registry of 37 centers with the enrollment of 395 chronic stable angina patients to examine the relation of the ER to post treatment improvement in Canadian Cardiovascular Society (CCS) angina class. After EECP, CCS improved by at least I class in $88 \%$ of patients, $87 \%$ of men and $92 \%$ of women. EECP is effective in improving CCS in chronic stable angina patients. Barsness et al. [19] performed a study on I $246 \mathrm{CHD}$ patients to determine whether EECP is a safe and effective treatment for patients with angina pectoris. The results demonstrated significant improvement in angina and reduction in nitroglycerine anti-angina drugs by $61.7 \%$. Springer et al. [20] conducted a study on $28 \mathrm{CHD}$ patients to assess psychological function and well-being status and observed significant improvement in psychological and well-being status. Lakshmi et al. [2I] carried out a study on 2486 patients those were enrolled in the IEPR. The study revealed a significant improvement in angina class in patients whose DA ratio was increased and results sustained for 6 months. Stys et al. [22] performed a study on 175 CHD patients and found a significant improvement in angina class in $85 \%$ of patients. This study results showed the EECP effectiveness in improving stress myocardial perfusion with exercise tolerance in CAD patients.

Michaels et al. [23] conducted a study on $10 \mathrm{CHD}$ patients and found the significant improvement in diastolic and mean pressures with reduction of systolic pressure in the central aorta and the coronary artery of CAD patients. The study concludes that EECP may serve as a potential mechanical assistant device for $C A D$ patients. Holubkov et al. [24] carried out a study on 77I CHD patients treated with EECP and the results of this study conclude that EECP may be a safe treatment option for
CAD patients. Soran et al. [25] performed a study on $1402 \mathrm{CHD}$ patients and the results showed that angina decreased by at least one class in $67 \%$ of patients with LV dysfunction just after completion of EECP treatment. Fitzgerald et al. [26] conducted a cohort study on 4669 CHD patients and found decreased angina episodes and nitroglycerin use and $74.8 \%$ reduction in Canadian Cardiovascular Society (CCS) functional class and improvement in angina sustained for 6 months. Bonetti et al. [27] performed a study on $23 \mathrm{CHD}$ patients to examine the effect of enhanced external counter pulsation (EECP) on endothelial function and found that $70 \%$ patients get symptomatic relief by EECP treatment. The author revealed that significant improvement in endothelial function by EECP may benefit to the clinical status of CHD patients.

Schecter et al. [28] carried out a study of 20 CHD patients to investigate the influence of short-term external counterpulsation (ECP) therapy on flow-mediated dilation (FMD) in patients with coronary artery disease (CAD). The author revealed that external counter pulsation may improve vascular endothelial function and refractory angina pectoris in CHD patients. Tartaglia et al. [29] conducted a study on 25 CHD patients to determine the effect of EECP on exercise capacity and myocardial perfusion by comparing results of maximal exercise radionuclide testing pre- and post-EECP treatment. A significant improvement in treadmill times has been reported and radionuclide perfusion scores also showed a significant reduction in ischemic segments. Werner et al. [30] performed a study on 48 CHD patients and weekly angina episodes were reduced by $48 \%$, nitroglycerin puffs were reduced by $51 \%$, work capacity was improved by $22 \%$. Study validates the reduction of angina with significant improvement of work capacity after EECP.

Lawson et al. [3I] carried out a study on 4592 CHD patients and his collected data from international enhanced external counter pulsation (EECP) patient regis- 
try showed significant improvement in angina by $73 \%$ in at least I class and 2 classes by $35.2 \%$ and 3 classes by $17.3 \%$. The mean angina episodes per week decrease to 2.5 per week after EECP treatment and nitroglycerine uses per week after EECP was 2.5 times per week and improvement in functional status also observed in the study. Linnemeier et al. [32] conducted a study on 3037 CHD patients to determine whether enhanced external counterpulsation is a safe and effective treatment for angina in octogenarians. At 6-month follow-up, 81\% of patients sustained angina improvement. This study concludes that enhanced external counterpulsation is effective and well tolerable non-invasive treatment. Linnemeier et al. [33] performed another study on I532 IEPR patients. The author demonstrated that after I year, maintenance of angina rate was reduced in $86 \%$ of patients with diabetes. This study also suggests that in diabetes patients, EECP can be a safe, effective, well-tolerated treatment option for the relief of angina. Bagger et al. [34] carried out a study on 23 patients with angina pectoris with positive dobutamine stress echocardiogram. This study was done to evaluate EECP effectiveness on dobutamine stress-induced wall motion score among angina patients. The reduction in dobutamine-induced wall motion abnormalities after EECP therapy was reported.

Michaels et al. [35] conducted the long-term outcomes of enhanced external counterpulsation in $1097 \mathrm{CHD}$ patients to relieve angina and improving the quality of life in a large cohort of patients with chronic angina pectoris. $73 \%$ patients had a reduction by at least I angina class at the end of treatment, and $50 \%$ reported an improvement in the quality-of-life assessment after enhanced external counterpulsation was; these results were sustained at 2-year follow-up. Lawson et al. [36] performed a study on 286I CHD patients to examine the safety and effectiveness of EECP therapy. Post-EECP, patients had improved their CCS angina by at least one class. At 6-month follow-up, the CCS-class improved reduction in angina episodes and nitroglycerin use. Enhanced external counterpulsation was proved an effective therapy in relieving angina in patient's angina patients. Masuda et al. [37] carried out a study on total $18 \mathrm{CHD}$ patients. Out of 18 patients, II were treated with EECP and 7 were treated $5000 \mathrm{IU}$ heparin pretreatment along with EECP. The study was done to evaluate EECP and intravenous heparin injection therapy effectiveness in angina pectoris patients and the results of the study showed significant improvement in exercise capacity and oxygen metabolism of coronary heart disease patients treated with combination therapy of EECP and heparin.

Henrikson et al. [38] conducted a study on $28 \mathrm{CHD}$ patients and found that post EECP most patients (82\%) had at least one full class improvement in their angina pattern. EECP remains an effective treatment for severe CAD. Taguchi et al. [39] performed study on 24 patients with myocardial infarction. This study was done to assess the haemodynamic effects of EECP and its mechanism with special reference to neurohumoral factors. The finding of this study suggests that an increase in ANP without an increase in BNP is an important mechanism for the effects of EECP therapy. Lawson et al. [40] carried out a study on 2007 CHD patients and demonstrated the angina reduction by $83 \%$ at least one CCS angina class and improvement in weekly angina episodes and their frequency of nitroglycerine use decreased with improvement in well-being status by $63 \%$. Michaels et al. [4I] conducted a study on II92 CHD patients to assess the frequency, efficacy, predictors, and long-term success of repeat enhanced external counter pulsation (EECP) therapy in relieving angina in a large cohort of angina patients. After 2 years of EECP therapy, $70 \%$ of patients reported the significant decrease in angina and nitroglycerine consumption. Arora et al. [42] performed a study on 30 patients with stable angina pectoris having class II-IV. This study was done to assess the effect of EECP on vascular cell release of coagulation factors. The author reveals that EECP may not play a significant role in controlling coagulation factors in CHD patients.

McCullough et al. [43] carried out a study on 2730 obese heart patients to evaluate the association of baseline body mass index (BMI) on the outcomes of enhanced external counterpulsation (EECP) therapy for chronic stable angina. A greater reduction in weekly angina episodes from baseline to follow up observed and study conclude that reduction of angina is directly proportional to BMI value. Akhtar et al. [44] conducted a study on $13 \mathrm{CHD}$ patients to evaluate the effect of EECP treatment on plasma nitric oxide and endothelin-I level. This study concludes that EECP may increase nitric oxide and decreases endothelin-I levels.

Soran et al. [45] carried out a cohort study on 363 CHD patients and post EECP treatment, there was a significant decrease in severity of angina class $(p<0.001)$, and $72 \%$ patients were improved from severe angina and $52 \%$ of patients discontinued nitroglycerin use. At 2 years of follow up 55\%, patients showed improvement in angina and prove that EECP is effective and durable therapy approach for CAD patients and $52 \%$ CHD patients discontinued nitroglycerin use. Nichols et al. [46] performed a study on 20 angina patients to prove the hypothesis of arterial properties and wave reflection characteristics favourably altered after EECP. The study revealed that EECP treatment may reduce arterial stiffness and can improve wave reflection characteristics in patients with angina. 
Lawson et al. [47] conducted a study on $1458 \mathrm{CHD}$ patients and found that EECP significantly reduced angina frequency, nitroglycerin use. Significant improvements in angina by $70-74 \%$ with reduction of nitroglycerine use by $52 \%$ with better well-being persist until 2 years of follow up. Novo et al. [48] carried out a study on $25 \mathrm{CHD}$ patients to evaluate the efficacy of EECP on clinical symptoms, myocardial ischemia and cardiac performed in intractable angina patients. 84 per cent of patients showed an increment in at least one functional angina class and reduced inducible ischemia and maximal benefits observed in patients with worst systolic failure had been observed.

Loh et al. [49] did a study on $58 \mathrm{CHD}$ patients to assess EECP immediate and long-term effectiveness in chronic stable refractory angina patients. This study results showed that angina improved at least one class CCS angina improvement by $78 \%$ after I year and increase exercise capacity with the reduction in nitroglycerine use. Arora et al. [50] conducted a study on II CHD patients to assess the effect of EECP on myocardial perfusion. In this study no significant effect on myocardial perfusion seen due to very less sample size and highly variable clinical responses. Michaels et al. [5I] performed a study on 27 patients and significant improvement in in heart rate variability in diabetic $\mathrm{CHD}$ patients and associated with reduced with reduced mortality rate had been reported. McCullough et al. [52] did a study on 902 patients from the IEPR. This study was done to evaluate the degree of residual angina on the clinical outcomes of EECP and conclude that residual high-grade angina pectoris occurs after post EECP in those patients who had the history of severe angina and multi-vessel disease.

Yavari et al. [53] conducted a study on $67 \mathrm{CHD}$ patients to assess EECP efficacy in relieving angina and improving myocardial ischemia. The results of this study conclude that EECP is safe, effective and well-tolerated therapy for angina pectoris treatment. Loh et al. [54] did a study on 1477 CHD patients to evaluate EECP effectiveness. Immediately after $E E C P$, angina reduction has been seen with $p<0.001$. The improvement in CCS class was improved by at least I class in $78 \%$ of the patients and by at least 2 classes in $38 \%$ and sustained in $74 \%$ of the patients during follow-up for 3 years. Erdling et al. [55] carried out a study on 86 CHD patients and conclude that after EECP treatment $79 \%$ of patients showed improvement in CCS class immediately and $61.5 \%$ of patients sustained these benefits till 12 months and $29 \%$ at 2 years follow up. The author concludes that EECP is safe \& effective for CAD with angina pectoris patients and patients with CCS angina class III \& IV reported maximum improvement. Buschmann et al. [56] conducted a study on $23 \mathrm{CHD}$ patients and found improvement in CCS and NYHA class in CAD patients with significant improvement in pressure derived collateral flow index and fractional flow, which also increased. Esmaeilzadeh et al. [57] performed a study on 20 CHD patients to assess the effects of EECP on cardiac functions and found a reduction in NYHA angina class. Significant improvement was observed in LV systolic, diastolic function in angina patient. Soran et al. [58] conducted a study on 2072 patients and treated with EECP. Significant reduction by $76-84 \%$ in the severity of angina in CAD patients at I year of follow up was reported and both US and turkey group got good results. Eslamian et al. [59] performed a study on 50 CHD patients to assess Enhanced External Counter Pulsation (EECP) effectiveness on clinical symptoms, echocardiographic measurements, and perfusion scan parameters and exercise tolerancetest. A significant improvement was observed in angina severity and wellbeing status. Bozorgi et al. [60] did a study on $20 \mathrm{CHD}$ patients with refractory angina. A significant reduction in angina classes III and IV was reported with sustained results for 6 months. The author concludes that EECP decreased symptoms and increased total exercise time and sustained these results for 6 months.

Beck et al. [6I] conducted a study on 24 CHD patients and significant improvement in plasma level of nitrates, improved peak VO2, and reduced LV function with significant improvement in peripheral vascular function and functional capacity had been reported. Tabary et al. [62] performed a study on $48 \mathrm{CHD}$ patients to assess clinical and para-clinical effects of enhanced external counterpulsation (EECP) effectiveness. Significant improvement in hemoglobin, LVEF, diastolic and systolic B.P, Chest pain, dyspnea and improvement in clinical conditions had been reported. Subramanian et al. [63] did a study on 72 CHD patients and found significant improvement in central systolic pressure, brachial systolic pressure, aortic pulse pressure, and augmentation pressure and augmentation index. Beck et al. [64] conducted the study on $17 \mathrm{CHD}$ patients. The author concludes that EECP may be useful as an adjuvant therapy for improving functional classification and improve central blood pressure, aortic pulse pressure, wasted left ventricular energy, andmyocardial oxygen demand in CHD patients.

\section{EFFECT OF EECP ON HR-QOL IN CORONARY HEART DISEASE PATIENTS}

Arora et al. [65] conducted a study to assess EECP effectiveness on HRQoL. A significant improvement in HRQoLwas observed at 12 months of follow up. The result shows improvements in HRQoL changes after EECP treatment. Kumar et al. [66] did a prospective 
study and found that EECP significantly improved angina symptoms, dyspnea on exertion, and quality of life after 35 days of treatment and at $I$ year follow up. EECP also improved the 6-minute walking capacity. Wu et al. [67] performed a study to evaluate EECP after six months regarding physical capacity and $H R Q \circ L$ in patients with refractory AP. Patients enhanced walking distance on average by $29 \mathrm{~m}$ after EECP. CCS class also improved and persisted at six months follow-up. HRQoL improved significantly and the effects maintained at follow-up after the treatment.

Ziaeirad et al. [68] did a quasi-experimental study on 64 patients to evaluate the QoL of patients with angina pectoris after treatment with enhanced external counterpulsation. The author reveals that EECP is an effective noninvasive method in treating patients with angina pectoris and in developing their HRQoL. Jorgensen et al. [69] conducted a special case study of the 43-year-old woman who had 15 hospital admissions in six years due to angina. The case study proves the EECP effectiveness towards angina recovery and significant improvement in HRQoL. May et al. [70] performed a study to assess the effect of EECP on QoL and exercise capacity in CAD patients. Author of this concludes that quality of life and exercise capacity was improved after EECP. Shakouri et al. [7I] conducted a study to investigate the effect of EECP on plasma nitric oxide (NO) and $H R Q \circ L$ in CAD patients. The author revealed that HRQoLand NO level increased after EECP treatment in CHD patients.Summary of studies given in Tables 3, 4 .

Table 3. EECP effectiveness on clinical profile in coronary heart disease patients

\begin{tabular}{|c|c|c|c|c|}
\hline Author & $\begin{array}{l}\text { Study } \\
\text { (year) }\end{array}$ & Title of study & $\begin{array}{l}\text { Sample } \\
\text { size }\end{array}$ & Findings $\&$ conclusion \\
\hline Lawson et al. [12] & 1992 & $\begin{array}{l}\text { Efficacy of enhanced external } \\
\text { counterpulsation in the treat- } \\
\text { ment of angina pectoris }\end{array}$ & 18 & $\begin{array}{l}\text { Myocardial ischemia } 67 \% \text { decrease, exercise } \\
\text { duration increased, reduction in anti-anginal } \\
\text { medicines and } 89 \% \text { patients were symptom-free }\end{array}$ \\
\hline Sjukri et al. [13] & 1995 & $\begin{array}{l}\text { EECP in the treatment and reha- } \\
\text { bilitation of coronary patients in } \\
\text { Indonesia }\end{array}$ & 201 & $\begin{array}{l}\text { Exercise tolerance } 94.2 \% \text {, improvement in CCS } \\
\text { angina class }\end{array}$ \\
\hline Arora et al. [14] & 1999 & $\begin{array}{l}\text { The multicenter study of enhan- } \\
\text { ced external counterpulsation } \\
\text { (MUST-EECP): effect of EECP } \\
\text { on exercise-induced myocardial } \\
\text { ischemia and anginal episodes }\end{array}$ & 139 & $\begin{array}{l}\text { Exercise duration increase, angina severity } \\
\text { reduced, extends times to exercise-induced } \\
\text { ischemia, Nitroglycerine usage decrease }\end{array}$ \\
\hline Lawson et al. [15] & 2000 & $\begin{array}{l}\text { Long-term prognosis of patients } \\
\text { with angina treated with enhan- } \\
\text { ced external counterpulsation: } \\
\text { five-year follow-up study }\end{array}$ & 33 & $\begin{array}{l}\text { Improvement in stress perfusion after EECP, } \\
64 \% \text { did not suffer any major adverse cardiova- } \\
\text { scular event due to the effect of EECP at } 5 \text { year } \\
\text { of study follow up }\end{array}$ \\
\hline Lawson et al. [16] & 2000 & $\begin{array}{l}\text { Treatment benefit in the enhan- } \\
\text { ced external counterpulsation } \\
\text { consortium }\end{array}$ & 2289 & $\begin{array}{l}74 \% \text { angina pectoris patients improved in CCS } \\
\text { angina class III \& IV with significant } p \text {-value } \\
(p<0.00 \text { I })\end{array}$ \\
\hline Urano et al. [I7] & 2001 & $\begin{array}{l}\text { Enhanced external counterpul- } \\
\text { sation improves exercise tole- } \\
\text { rance, reduces exercise-induced } \\
\text { myocardial ischemia, and impro- } \\
\text { ves left ventricular diastolic filling } \\
\text { in patients with coronary artery } \\
\text { disease }\end{array}$ & 512 & $\begin{array}{l}\text { Improvement in Exercise duration and toleran- } \\
\text { ce with improvement in LV function. } \\
\text { Improvement in diastolic filling and diastolic } \\
\text { function }\end{array}$ \\
\hline Stys et al. [18] & 2001 & $\begin{array}{l}\text { Acute hemodynamic effects } \\
\text { and angina improvement with } \\
\text { enhanced external counterpul- } \\
\text { sation }\end{array}$ & 395 & $\begin{array}{l}\text { CCS angina class improvement by at least I } \\
\text { class in } 88 \% \text { of patients }\end{array}$ \\
\hline Barsness et al. [19] & 2001 & $\begin{array}{l}\text { The International EECP Pa- } \\
\text { tient Registry (IEPR): design, } \\
\text { methods, baseline characteri- } \\
\text { stics and acute results }\end{array}$ & 1246 & $\begin{array}{l}\text { Decrease in at least I anginal class by } 81 \% \text { and } \\
\text { mean change decrease in anginal episodes per } \\
\text { week }(6.4 \pm 12.6) \text { with reduction of nitrogly- } \\
\text { cerine use by } 61.7 \%\end{array}$ \\
\hline Springer et al. [20] & 2001 & $\begin{array}{l}\text { Psychosocial effects of EECP in } \\
\text { the angina patient: A second } \\
\text { study }\end{array}$ & 28 & $\begin{array}{l}\text { Improvement in physical functioning and mental } \\
\text { health with special reference to stress and QoL }\end{array}$ \\
\hline
\end{tabular}


Table 3. cont. EECP effectiveness on clinical profile in coronary heart disease patients

\begin{tabular}{|c|c|c|c|c|}
\hline Author & $\begin{array}{l}\text { Study } \\
\text { (year) }\end{array}$ & Title of study & $\begin{array}{l}\text { Sample } \\
\text { size }\end{array}$ & Findings \& conclusion \\
\hline Lakshmi et al. [2I] & 2002 & $\begin{array}{l}\text { Relation of the Pattern of Dia- } \\
\text { stolic Augmentation During a } \\
\text { Course of Enhanced External } \\
\text { Counterpulsation (EECP) to } \\
\text { Clinical Benefit (from the Inter- } \\
\text { national EECP Patient Registry } \\
\text { [IEPR]) }\end{array}$ & 2486 & $\begin{array}{l}\text { At } 6 \text { months of follow up, the patients showed } \\
\text { a higher reduction in angina class who had the } \\
\text { greatest increase in the DA ratio as compared } \\
\text { to those who had a decrease in the DA ratio }\end{array}$ \\
\hline Stys et al. [22] & 2002 & $\begin{array}{l}\text { Effects of enhanced external } \\
\text { counterpulsation on stress ra- } \\
\text { dionuclide coronary perfusion } \\
\text { and exercise capacity in chronic } \\
\text { stable angina pectoris }\end{array}$ & 175 & $\begin{array}{l}85 \% \text { angina improvement, improvement in } \\
\text { stress myocardial perfusion and maximize exer- } \\
\text { cise functions }\end{array}$ \\
\hline Michaels et al. [23] & 2002 & $\begin{array}{l}\text { Left ventricular systolic unlo- } \\
\text { ading and augmentation of intra- } \\
\text { coronary pressure and Doppler } \\
\text { flow during enhanced external } \\
\text { counterpulsation }\end{array}$ & 10 & $\begin{array}{l}\text { Diastolic BP increase, Systolic B.P decrease } \\
\text { and increment in coronary flow by } 28 \% \text { during } \\
\text { EECP treatment }\end{array}$ \\
\hline Holubkov et al. [24] & 2002 & $\begin{array}{l}\text { Comparison of patients under- } \\
\text { going enhanced external coun- } \\
\text { terpulsation and percutaneous } \\
\text { coronary intervention for stable } \\
\text { angina pectoris }\end{array}$ & 771 & $\begin{array}{l}\text { Angina improvement in CCS class higher who } \\
\text { received EECP therapy as compared to } \mathrm{PCl} \\
\text { group }\end{array}$ \\
\hline Soran et al. [25] & 2002 & $\begin{array}{l}\text { Enhanced external counterpul- } \\
\text { sationas treatment for chronic } \\
\text { angina in patients with left ven- } \\
\text { tricular dysfunction: a report } \\
\text { from the International EECP } \\
\text { Patient Registry (IEPR) }\end{array}$ & 1402 & $\begin{array}{l}\text { Improvement in angina at least one class in } \\
67 \% \text { of patients with LV dysfunction } 70.6 \% \text { after } \\
6 \text { months of follow up }\end{array}$ \\
\hline Fitzgerald et al. [26] & 2003 & $\begin{array}{l}\text { Enhanced external counterpul- } \\
\text { sation as initial revascularization } \\
\text { treatment for angina refractory } \\
\text { to medical therapy }\end{array}$ & 4,669 & $\begin{array}{l}\text { The decrease in anginal episode per week with } \\
\text { significant value } p<0.00 \mathrm{I} \text {, reduced nitrogly- } \\
\text { cerine uses and CCS angina class reduction } \\
\text { in } 74.8 \text { patients }\end{array}$ \\
\hline Bonetti et al. [27] & 2003 & $\begin{array}{l}\text { Enhanced external counter- } \\
\text { pulsation improves endothelial } \\
\text { function in patients with symp- } \\
\text { tomatic CAD }\end{array}$ & 23 & $\begin{array}{l}\text { Enhanced peripheral endothelial function imme- } \\
\text { diately after EECP treatment with a contribu- } \\
\text { tion to the clinical benefit of EECP }\end{array}$ \\
\hline Schecter et al. [28] & 2003 & $\begin{array}{l}\text { External counterpulsation thera- } \\
\text { py improves endothelial function } \\
\text { in patients with refractory angina } \\
\text { pectoris }\end{array}$ & 20 & $\begin{array}{l}\text { Significant improvement in angina class } \\
(p<0.00 I) \text {, nitrate consumption decrease } \\
(p<0.00 I) \text { with improvement in endothelial } \\
\text { functions }\end{array}$ \\
\hline Tartaglia et al. [29] & 2003 & $\begin{array}{l}\text { Exercise capability and myocar- } \\
\text { dial perfusion in chronic angina } \\
\text { patients treated with enhanced } \\
\text { external counterpulsation }\end{array}$ & 25 & $\begin{array}{l}96 \% \text { patients improved by at least one functio- } \\
\text { nal angina class and exercise duration increased } \\
\text { in treadmill exercise testing and reduction in } \\
\text { ischemic segments }\end{array}$ \\
\hline Werner et al. [30] & 2003 & $\begin{array}{l}\text { Practicability and limitations of } \\
\text { enhanced external counterpul- } \\
\text { sation as an additional treatment } \\
\text { for angina }\end{array}$ & 48 & $\begin{array}{l}\text { Anginal episode reduced by } 48 \% \text {, Nitrogly- } \\
\text { cerine reduction by } 51 \% \text { and work capacity } \\
\text { increase by } 22 \%\end{array}$ \\
\hline
\end{tabular}


Table 3. cont. EECP effectiveness on clinical profile in coronary heart disease patients

\begin{tabular}{|c|c|c|c|c|}
\hline Author & $\begin{array}{l}\text { Study } \\
\text { (year) }\end{array}$ & Title of study & $\begin{array}{l}\text { Sample } \\
\text { size }\end{array}$ & Findings \& conclusion \\
\hline Lawson et al. [3I] & 2003 & $\begin{array}{l}\text { Analysis of baseline factors } \\
\text { associated with a reduction in } \\
\text { chest pain in patients with angina } \\
\text { pectoris treated by enhanced } \\
\text { external counterpulsation }\end{array}$ & 4592 & $\begin{array}{l}\text { Significant improvement in angina by } 73 \% \text { in at } \\
\text { least I class and } 2 \text { classes by } 35.2 \% \text { and } 3 \text { clas- } \\
\text { ses by } 17.3 \% \text {. Mean angina episodes per week } \\
\text { decrease to } 2.5 \text { per week after EECP treatment } \\
\text { and nitroglycerine uses per week after EECP } \\
\text { was } 2.5 \text { times per week and improvement in } \\
\text { functional status also observed }\end{array}$ \\
\hline Linnemeier et al. [32] & 2003 & $\begin{array}{l}\text { Enhanced external counterpul- } \\
\text { sation in the management of } \\
\text { angina in the elderly }\end{array}$ & 3037 & $\begin{array}{l}\text { Angina improvement in } 81 \% \text { at } 6 \text { months with } \\
\text { a reduction in nitroglycerine use and improve- } \\
\text { ment in well-being status with decrease rate of } \\
\text { cardiac hospitalization has been observed }\end{array}$ \\
\hline Linnemeier et al. [33] & 2003 & $\begin{array}{l}\text { Enhanced External Counterpul- } \\
\text { sation for the relief of angina in } \\
\text { patients with diabetes: safety, } \\
\text { efficacy and I- year clinical } \\
\text { outcomes }\end{array}$ & 1532 & $\begin{array}{l}\text { Significant improvement in CCS angina class } \\
\text { by } 69 \% \text { in diabetes mellitus immediately after } \\
\mathrm{EECP} \text { and } 86 \% \text { at I year follow up, reduction } \\
\text { in nitroglycerine use and improvement in well- } \\
\text {-being status has been observed and confirm } \\
\text { that EECP is safe, effective and well tolerable } \\
\text { treatment }\end{array}$ \\
\hline Bagger et al. [34] & 2004 & $\begin{array}{l}\text { Effect of enhanced external co- } \\
\text { unterpulsation on dobutamine- } \\
\text {-induced left ventricular wall } \\
\text { motion abnormalities in severe } \\
\text { chronic angina pectoris }\end{array}$ & 23 & $\begin{array}{l}\text { Reduction in dobutamine-induced wall motion } \\
\text { abnormalities observed after EECP treatment }\end{array}$ \\
\hline Michaels et al. [35] & 2004 & $\begin{array}{l}\text { Two-year outcomes after enhan- } \\
\text { ced external counterpulsation } \\
\text { for stable angina pectoris (from } \\
\text { the International EECP patient } \\
\text { registry [IEPR]) }\end{array}$ & 1097 & $\begin{array}{l}\text { Significant improvement by } 73 \% \text { angina impro- } \\
\text { vement , } 50 \% \text { improvement in well-being of } \\
\text { CAD patients at } 2 \text { years of follow up }\end{array}$ \\
\hline Lawson et al. [36] & 2004 & $\begin{array}{l}\text { The effectiveness of enhanced } \\
\text { external counterpulsation in } \\
\text { patients with left main disease } \\
\text { and angina. }\end{array}$ & 2861 & $\begin{array}{l}\text { Significant improvement in angina pectoris and } \\
\text { reduction in nitroglycerine use and reduction in } \\
\text { weekly angina episodes observed }\end{array}$ \\
\hline Masuda et al. [37] & 2004 & $\begin{array}{l}\text { Improvement of oxygen meta- } \\
\text { bolism in ischemic myocardium } \\
\text { as a result of enhanced external } \\
\text { counterpulsation with heparin } \\
\text { pretreatment for patients with } \\
\text { stable angina }\end{array}$ & 18 & $\begin{array}{l}\text { Significant improvement in exercise capacity and } \\
\text { oxygen metabolism of CHD patients treated } \\
\text { with EECP and intravenous heparin infusion } \\
\text { combined therapy was observed }\end{array}$ \\
\hline $\begin{array}{l}\text { Henrikson et al. } \\
\text { [38] }\end{array}$ & 2004 & $\begin{array}{l}\text { Enhanced external counterpul- } \\
\text { sation therapy: significant clinical } \\
\text { improvement without electrop- } \\
\text { hysiologic remodelling }\end{array}$ & 28 & $\begin{array}{l}\text { Significant improvement in angina by } 82 \% \text { and } \\
\text { effective treatment for CAD patients }\end{array}$ \\
\hline Taguchi et al. [39] & 2004 & $\begin{array}{l}\text { Effects of enhanced external } \\
\text { counterpulsation on hemodyna- } \\
\text { mics and its mechanism relation } \\
\text { to neurohumoral factors }\end{array}$ & 24 & $\begin{array}{l}\text { Study concludes that increments in ANP wit- } \\
\text { hout enhancement in BNP was an important } \\
\text { mechanism for EECP effectiveness }\end{array}$ \\
\hline Lawson et al. [40] & 2005 & $\begin{array}{l}\text { Predictors of benefit in an- } \\
\text { gina patients one year after } \\
\text { completing enhanced external } \\
\text { counterpulsation: initial respon- } \\
\text { ders to treatment versus non } \\
\text { responders }\end{array}$ & 2,007 & $\begin{array}{l}\text { Angina reduced by at least } 83 \% \text { immediately, } \\
\text { and improvement in weekly anginal episodes, } \\
\text { the frequency of nitroglycerine use decreased } \\
\text { and well-being status improved by } 63 \%\end{array}$ \\
\hline
\end{tabular}


Table 3. cont. EECP effectiveness on clinical profile in coronary heart disease patients

\begin{tabular}{|c|c|c|c|c|}
\hline Author & $\begin{array}{l}\text { Study } \\
\text { (year) }\end{array}$ & Title of study & $\begin{array}{l}\text { Sample } \\
\text { size }\end{array}$ & Findings \& conclusion \\
\hline Michaels et al. [4I] & 2005 & $\begin{array}{l}\text { Frequency and efficacy of repeat } \\
\text { enhanced external counterpul- } \\
\text { sation for stable angina pectoris } \\
\text { (from the International EECP } \\
\text { Patient Registry) }\end{array}$ & 1192 & $\begin{array}{l}\text { After EECP treatment } 86 \% \text { reported decrease } \\
\text { in angina CCS class by at least one and } 57 \% \text { pa- } \\
\text { tients discontinued nitroglycerine use } \\
\text { After } 2 \text { years } 70 \% \text { patients reported significant } \\
\text { decrease in angina and nitroglycerine consumption }\end{array}$ \\
\hline Arora et al. [42] & 2005 & $\begin{array}{l}\text { Effects of enhanced counterpul- } \\
\text { sation on vascular cell release of } \\
\text { coagulation factors }\end{array}$ & 30 & $\begin{array}{l}\text { The study suggests that EECP may not play a } \\
\text { vital role in controlling coagulation factors in co- } \\
\text { ronary heart disease patients, further research } \\
\text { required }\end{array}$ \\
\hline McCullough et al. [43] & 2006 & $\begin{array}{l}\text { Impact of body mass index on } \\
\text { outcomes of enhanced external } \\
\text { counterpulsation therapy }\end{array}$ & 2730 & $\begin{array}{l}\text { Changes in angina and duke activity status have } \\
\text { been observed in all BMI patients. Greater re- } \\
\text { duction of angina is directly proportional to BMI } \\
\text { value }\end{array}$ \\
\hline Soran et al. [44] & 2006 & $\begin{array}{l}\text { Two-year outcomes after enhan- } \\
\text { ced external counterpulsation } \\
\text { (EECP) therapy in patients } \\
\text { with refractory angina pectoris } \\
\text { and left ventricular dysfunction } \\
\text { (report from the International } \\
\text { EECP Patient Registry) }\end{array}$ & 363 & $\begin{array}{l}\text { At } 2 \text { years of follow up } 55 \% \text { of patients showed } \\
\text { improvement in angina and prove that EECP is } \\
\text { effective and durable therapy approach for CAD } \\
\text { patients and } 52 \% \text { CHD patients discontinued } \\
\text { nitroglycerin use }\end{array}$ \\
\hline Akhtar et al. [45] & 2006 & $\begin{array}{l}\text { Effect of external counterpulsa- } \\
\text { tion on plasma nitric oxide and } \\
\text { endothelin-I levels }\end{array}$ & 13 & $\begin{array}{l}\text { EECP increases nitric oxide and decreases } \\
\text { endothelial-I level and changes sustained } \\
\text { for } 3 \text { months in CHD patients }\end{array}$ \\
\hline Nichols et al. [46] & 2006 & $\begin{array}{l}\text { Enhanced external counterpulsa- } \\
\text { tion treatment improves arterial } \\
\text { wall properties and wave reflec- } \\
\text { tion characteristics in patients } \\
\text { with refractory angina }\end{array}$ & 20 & $\begin{array}{l}\text { The study suggests that EECP can reduce } \\
\text { arterial stiffness and may improve wave reflec- } \\
\text { tion characteristics in CHD patients and these } \\
\text { changes decrease left ventricular afterload, my- } \\
\text { ocardial oxygen demand and can reduce anginal } \\
\text { episodes }\end{array}$ \\
\hline Lawson et al. [47] & 2006 & $\begin{array}{l}\text { Two-year outcomes in patients } \\
\text { with mild refractory angina } \\
\text { treated with enhanced external } \\
\text { counterpulsation }\end{array}$ & 1458 & $\begin{array}{l}\text { Improvement in angina by } 70-74 \% \text { with re- } \\
\text { duction of nitroglycerine use by } 52 \% \text { with bet- } \\
\text { ter well-being persist till } 2 \text { years of follow up }\end{array}$ \\
\hline Novo et al. [48] & 2006 & $\begin{array}{l}\text { Enhanced external counterpulsa- } \\
\text { tion for treatment of refractory } \\
\text { angina pectoris }\end{array}$ & 25 & $\begin{array}{l}\text { Significant improvement in angina by } 84 \% \text { and } \\
\text { reduced inducible ischemia and maximal bene- } \\
\text { fits observed in patients with the worst systolic } \\
\text { failure }\end{array}$ \\
\hline Loh et al. [49] & 2006 & $\begin{array}{l}\text { The immediate and long-term } \\
\text { outcome of enhanced external } \\
\text { counterpulsation in treatment of } \\
\text { chronic stable refractory angina }\end{array}$ & 58 & $\begin{array}{l}\text { At least one class CCS angina improvement by } \\
78 \% \text { after I year and increase exercise capacity } \\
\text { with a reduction in nitroglycerine use }\end{array}$ \\
\hline Arora et al. [50] & 2007 & $\begin{array}{l}\text { Effect of enhanced external } \\
\text { counterpulsation on myocardial } \\
\text { perfusion in patients with stable } \\
\text { angina: A multicenter radionuc- } \\
\text { lide study }\end{array}$ & 11 & $\begin{array}{l}\text { No significant effect on myocardial perfusion } \\
\text { has been observed due to very less number of } \\
\text { sample size and highly variable clinical responses } \\
\text { and study suggest for further research to assess } \\
\text { EECP effectiveness on myocardial perfusion }\end{array}$ \\
\hline Michaels et al. [5I] & 2007 & $\begin{array}{l}\text { The effects of enhanced external } \\
\text { counterpulsation on time- and } \\
\text { frequency-domain measures of } \\
\text { heart rate variability }\end{array}$ & 27 & $\begin{array}{l}\text { Improvement in heart rate variability in diabetic } \\
\mathrm{CHD} \text { patients and associated with reduced with } \\
\text { reduced mortality rate }\end{array}$ \\
\hline
\end{tabular}


Table 3. cont. EECP effectiveness on clinical profile in coronary heart disease patients

\begin{tabular}{|c|c|c|c|c|}
\hline Author & $\begin{array}{l}\text { Study } \\
\text { (year) }\end{array}$ & Title of study & $\begin{array}{l}\text { Sample } \\
\text { size }\end{array}$ & Findings $\&$ conclusion \\
\hline McCullough [52] & 2007 & $\begin{array}{l}\text { Residual high-grade angina after } \\
\text { enhanced external counterpulsa- } \\
\text { tion therapy }\end{array}$ & 902 & $\begin{array}{l}\text { The researcher observed high residual grade } \\
\text { angina after EECP in those patients who had } \\
\text { severe angina and multivessel diseases }\end{array}$ \\
\hline Yavari et al. [53] & 2007 & $\begin{array}{l}\text { Effects of enhanced external } \\
\text { counterpulsation on anginal } \\
\text { symptoms and improvements in } \\
\text { objective measures of myocardial } \\
\text { ischaemia }\end{array}$ & 67 & $\begin{array}{l}\text { The study concludes that EECP is a safe, well } \\
\text { tolerated and effective non-invasive therapy for } \\
\text { CHD patients }\end{array}$ \\
\hline Loh et al. [54] & 2008 & $\begin{array}{l}\text { Enhanced external counter- } \\
\text { pulsation in the treatment of } \\
\text { chronic refractory angina: a } \\
\text { long-term follow-up outcome } \\
\text { from the International Enhanced } \\
\text { External Counterpulsation } \mathrm{Pa} \text { - } \\
\text { tient Registry }\end{array}$ & 1477 & $\begin{array}{l}\text { After I-year EECP treatment } 78 \% \text { patients re- } \\
\text { ported reduction in CCS angina class and } 74 \% \\
\text { of patients sustained improvement at 3-years } \\
\text { follow }\end{array}$ \\
\hline Erdling et al. [55] & 2008 & $\begin{array}{l}\text { Enhanced external counter pul- } \\
\text { sation in treatment of refractory } \\
\text { angina pectoris: two-year outco- } \\
\text { me and baseline factors associa- } \\
\text { ted with treatment failure }\end{array}$ & 86 & $\begin{array}{l}\text { After EECP treatment } 79 \% \text { of patients showed } \\
\text { improvement in CCS class immediately and } \\
61.5 \% \text { of patients sustained these benefits till I } 2 \\
\text { months and } 29 \% \text { at } 2 \text { years follow up and study } \\
\text { conclude that EECP is safe \& effective for CAD } \\
\text { with angina pectoris patients and patients with } \\
\text { CCS angina class III \& IV reported maximum } \\
\text { improvement }\end{array}$ \\
\hline Buschmann et al. [56] & 2009 & $\begin{array}{l}\text { Improvement of fractional flow } \\
\text { reserve and collateral flow by } \\
\text { treatment with external coun- } \\
\text { terpulsation. }\end{array}$ & 23 & $\begin{array}{l}\text { Improvement in CCS and NYHA class in CAD } \\
\text { patients with significant improvement in pres- } \\
\text { sure derived collateral flow index and fractional } \\
\text { flow also increased }\end{array}$ \\
\hline $\begin{array}{l}\text { Esmaeilzadeh et } \\
\text { al. [57] }\end{array}$ & 2009 & $\begin{array}{l}\text { Evaluation of left ventricular } \\
\text { systolic and diastolic regional } \\
\text { function after enhanced external } \\
\text { counter pulsation therapy using } \\
\text { strain rate imaging }\end{array}$ & 20 & $\begin{array}{l}\text { Reduction in NYHA angina class \& improvement } \\
\text { in LV systolic and diastolic function in patients } \\
\text { with chronic angina with increment in LVEF } \\
\text { from } 40.25-46.25 \% \text { with significant } p \text {-value } \\
(p<0.001)\end{array}$ \\
\hline Soran et al. [58] & 2012 & $\begin{array}{l}\text { Comparison of long-term clinical } \\
\text { outcomes, event-free survival } \\
\text { rates of patients undergoing } \\
\text { enhanced external counterpulsa- } \\
\text { tion for coronary artery disease } \\
\text { in the united states and turkey }\end{array}$ & 2072 & $\begin{array}{l}\text { Significant reduction in the severity of angina in } \\
\text { CAD patients at I-year of follow up }\end{array}$ \\
\hline Eslamian et al. [59] & 2013 & $\begin{array}{l}\text { Therapeutic effects of enhan- } \\
\text { ced external counterpulsation } \\
\text { on clinical sumptoms, echo- } \\
\text { cardiographic measurements, } \\
\text { perfusion scan parameters and } \\
\text { exercise tolerance test in CAD } \\
\text { patients with refractory angina }\end{array}$ & 50 & $\begin{array}{l}\text { Significant improvement in angina severity } \\
(p<0.00 I) \text {, wellbeing status and ischemia } \\
\text { severity }(p=0.044) \text { and demonstrated useful } \\
\text { safe and effective treatment method for angina } \\
\text { pectoris in CHD patients }\end{array}$ \\
\hline Bozorgi et al. [60] & 2014 & $\begin{array}{l}\text { Effect of enhanced external co- } \\
\text { unterpulsation (EECP) on exerci- } \\
\text { se time duration and } \\
\text { functional capacity in patients } \\
\text { with refractory angina pectoris }\end{array}$ & 20 & $\begin{array}{l}\text { Significant reduction in the severity of angina } \\
\text { and physical functioning sustained for } 6 \text { months }\end{array}$ \\
\hline
\end{tabular}


Table 3. cont. EECP effectiveness on clinical profile in coronary heart disease patients

\begin{tabular}{|c|c|c|c|c|}
\hline Author & $\begin{array}{l}\text { Study } \\
\text { (year) }\end{array}$ & Title of study & $\begin{array}{l}\text { Sample } \\
\text { size }\end{array}$ & Findings \& conclusion \\
\hline Beck et al. [6I] & 2014 & $\begin{array}{l}\text { Enhanced external counter- } \\
\text { pulsation improves endothelial } \\
\text { function and exercise capacity in } \\
\text { patients with ischaemic left ven- } \\
\text { tricular dysfunction }\end{array}$ & 24 & $\begin{array}{l}\text { Significant improvement in plasma level of nitra- } \\
\text { tes and improved peak } \mathrm{VO}_{2} \text { and reduce } \mathrm{LV} \text { fun- } \\
\text { ction with significant improvement in peripheral } \\
\text { vascular function and functional capacity }\end{array}$ \\
\hline Tabary et al. [62] & 2015 & $\begin{array}{l}\text { The assessment of the clinical } \\
\text { and paraclinical effects of enhan- } \\
\text { ced external counter pulsation } \\
\text { therapy in patients with corona- } \\
\text { ry artery disease }\end{array}$ & 48 & $\begin{array}{l}\text { Improvement in Hemoglobin, LVEF, Diastolic } \\
\text { and systolic B.P, Chest pain, dyspnea and impro- } \\
\text { ve clinical conditions }\end{array}$ \\
\hline $\begin{array}{l}\text { Subramanian et } \\
\text { al. [63] }\end{array}$ & 2016 & $\begin{array}{l}\text { Effect of enhanced external } \\
\text { counter pulsation treatment on } \\
\text { aortic blood pressure, arterial } \\
\text { stiffness and ejection fraction in } \\
\text { patients with coronary artery } \\
\text { disease }\end{array}$ & 72 & $\begin{array}{l}\text { Central B.P significantly decrease with improve- } \\
\text { ment in LV function in CAD patients }\end{array}$ \\
\hline Beck et al. [64] & 2016 & $\begin{array}{l}\text { Enhanced external counter pul- } \\
\text { sation reduces indices of central } \\
\text { blood pressure and myocardial } \\
\text { oxygen demand in patients with } \\
\text { left ventricular dysfunction }\end{array}$ & 17 & $\begin{array}{l}\text { EECP worked as adjuvant therapy and impro- } \\
\text { vement in functional status, central B.P and my- } \\
\text { ocardial oxygen demand in CAD patients }\end{array}$ \\
\hline
\end{tabular}

Table 4. EECP effectiveness on health-related the fuality of life in coronary heart disease patients

\begin{tabular}{|c|c|c|c|c|}
\hline Author & $\begin{array}{l}\text { Study } \\
\text { (year) }\end{array}$ & Title of study & $\begin{array}{l}\text { Sample } \\
\text { size }\end{array}$ & Findings $\&$ conclusion \\
\hline Arora et al. [65] & 2002 & $\begin{array}{l}\text { Effects of enhanced external } \\
\text { counterpulsation on health- } \\
\text {-related quality of life continue } \\
\text { I } 2 \text { months after treatment: a } \\
\text { substudy of the multicenter } \\
\text { study of enhanced external co- } \\
\text { unterpulsation }\end{array}$ & 139 & $\begin{array}{l}\text { Significant improvement in Health-related QoL } \\
\text { in patients who had active EECP as compare to } \\
\text { those having inactive EECP in all HR-QoL para- } \\
\text { meters }(p<0.05)\end{array}$ \\
\hline Kumar et al. [66] & 2009 & $\begin{array}{l}\text { Effect of enhanced external co- } \\
\text { unterpulsation on clinical symp- } \\
\text { toms, quality of life, 6-minute } \\
\text { walking distance, and echocar- } \\
\text { diographic measurements of left } \\
\text { ventricular systolic and diastolic } \\
\text { function after } 35 \text { days of treat- } \\
\text { ment and at I-year follow up in } \\
47 \text { patients with chronic refrac- } \\
\text { tory angina pectoris }\end{array}$ & 47 & $\begin{array}{l}\text { Significant improvement in QoL and walking } \\
\text { capacity }\end{array}$ \\
\hline Wu et al. [67] & 2012 & $\begin{array}{l}\text { Enhanced external counterpul- } \\
\text { sation in patients with refractory } \\
\text { angina pectoris: a pilot study } \\
\text { with six months follow-up re- } \\
\text { garding physical capacity and } \\
\text { health-related quality of life }\end{array}$ & 34 & $\begin{array}{l}\text { Improvement in physical and functional capacity } \\
\text { with HR-QoL improvement }\end{array}$ \\
\hline Ziaeirad et al. [68] & 2012 & $\begin{array}{l}\text { The effects of enhanced external } \\
\text { counterpulsation on health- } \\
\text {-related quality of life in patients } \\
\text { with angina pectoris }\end{array}$ & 64 & Angina \& QoL improvement \\
\hline
\end{tabular}


Table 4. cont. EECP effectiveness on health-related the fuality of life in coronary heart disease patients

\begin{tabular}{|l|l|l|l|l|}
\hline Author & $\begin{array}{l}\text { Study } \\
\text { (year) }\end{array}$ & Title of study & SoL \& Angina improvement \\
\hline Jorgensen et al. [69] & 2013 & $\begin{array}{l}\text { Improvement of angina, quality } \\
\text { of life, and working capacity } \\
\text { after enhanced external coun- } \\
\text { terpulsation }\end{array}$ & $\begin{array}{l}\text { One } \\
\text { special } \\
\text { case }\end{array}$ & QoL Ample Findings \& conclusion \\
\hline May et al. [70] & 2015 & $\begin{array}{l}\text { Enhanced external counterpul- } \\
\text { sation - effect on angina pec- } \\
\text { toris, QoL and exercise capacity } \\
\text { after I year }\end{array}$ & 50 & $\begin{array}{l}\text { Improvement in exercise capacity with generic } \\
\text { and disease speacific QoL improvement }\end{array}$ \\
\hline Shakouri [7I] & 2015 & $\begin{array}{l}\text { Effect of enhanced external } \\
\text { counterpulsation and cardiac } \\
\text { rehabilitation on quality of life, } \\
\text { plasma nitric oxide, endothelin } \\
\text { and high sensitive crp in patients } \\
\text { with coronary artery disease: a } \\
\text { pilot study }\end{array}$ & 42 & $\begin{array}{l}\text { Mean change in quality of life and endothelial } \\
\text { functioning has been observed in CAD patients }\end{array}$ \\
\hline
\end{tabular}

\section{Discussion}

Above discussed EECP studies validates the significant improvement in CCS and NYHA angina classification, angina episodes, left ventricle ejection fraction functioning, exercise tolerance and HRQoL with reduction of nitroglycerine use \& decrease hospitalization rate in coronary heart disease patients. EECP used for angina and heart failure for the past two decades, but still, more research required filling the gaps in research. There are very few or rare study conducted to assess EECP effectiveness on BMI, Heart Rate, Cholesterol, Triglyceride, High-Density Lipoprotein (HDL), Low-Density Lipoprotein (LDL), $\mathrm{HbAIC}, \mathrm{SpO}_{2}$, Vo2max, I2-minute walk or run test and comparative prospective randomized trials on cardiac and non-cardiac metabolic markers.

\section{Conclusion}

Further clinical research is required to evaluate EECP effectiveness on obese, diabetic, hypertension and other metabolic disease patients with CHD and multi-centric randomized controlled trials are required for further modifications in EECP device to cure, prevent, and treat chronic diseases such as obesity, hypertension, diabetes, and neurological disorders by the non-invasive procedure.

\section{Conflict of interest}

None.

\section{Acknowledgements}

Special thanks to all healthcare professionals of SAAOL Heart Center for their contribution in EECP treatment and systematic review article.

\section{References:}

I. Gupta R, Mohan I, Narula J. Trends in Coronary Heart Disease Epidemiology in India. Ann Glob Health. 2016; 82(2): 307-315, doi: 10.1016/j.aogh.2016.04.002, indexed in Pubmed: 27372534.

2. Pradhan A. Cardiovascular risk screening: Time for a wakeup call! Heart India. 2016; 4(I): 3, doi: 10.4103/232।-449x. I78। 16.

3. Prasad GN, Ramasamy S, Thomas JM, et al. Enhanced external counterpulsation (EECP) therapy: current evidence for clinical practice and who will benefit? Indian Heart J. 2010; 62(4): 296-302, indexed in Pubmed: 21280467.

4. Kantrowitz A. Experimental augmentation of coronary flow by retardation of the arterial pressure pulse. Surgery. 1953; 34(4): 678-687, indexed in Pubmed: 13102153.

5. Birtwell WC, Ruitz U, Soroff HS. Technical consideration in the design of a clinical system for external left ventricular assist by synchronous pulsation of extramural pressure. Surg Forum. 1965; 16: 148-150.

6. Birtwell WC, Ruiz U, Soroff HS, et al. Technical consideration in the design of a clinical system for the external left ventricular assist. Trans Am SocArtif Intern Organs. 1968; 14: 304-310.

7. Zheng ZS, Li TM, Kambic H, et al. Sequential external counterpulsation (SECP) in China. Trans Am Soc Artif Intern Organs. 1983; 29: 599-603, indexed in Pubmed: 6673295.

8. Kumar S, Lahiri TK. Enhanced external counter pulsation as an effective nonsurgical solution for ischemic heart disease patients. Heart India. 2017; 5: 55-60.

9. Prasad GN, Ramasamy S, Thomas JM, et al. Enhanced external counterpulsation (EECP) therapy: current evidence for clinical practice and who will benefit? Indian Heart J. 2010; 62(4): 296-302, indexed in Pubmed: 21280467.

10. Sayami LA, Ullah M, Rahman MT, et al. Enhanced External Counterpulsation - A Review. Cardiovascular Journal. 2010; 2(2): 236-244, doi: 10.3329/cardio.v2i2.6647.

II. Manchanda A, Soran O. Enhanced external counterpulsation and future directions: step beyond medical management for patients with angina and heart failure. J Am Coll Cardiol. 2007; 50(16): |523-1531, doi: 10.1016/j.jacc.2007.07.024, indexed in Pubmed: I7936।50. 
12. Michaels AD, McCullough PA, Soran OZ, et al. International EECP Patient Registry Investigators. Efficacy of enhanced external counterpulsation in the treatment of angina pectoris. Am J Cardiol. 1992; 70(9): 859-862, indexed in Pubmed: 1529937.

13. Karim S, Sani A, Karo-Karo S, et al. Enhanced External Counterpulsation in the Treatment and Rehabilitation of Coronary Patients in Indonesia. Asian Cardiovascular and Thoracic Annals. 2016; 3(I): 26-28, doi: 10.1177/021849239500300108.

14. Arora RR, Chou TM, Jain D, et al. The multicenter study of enhanced external counterpulsation (MUST-EECP): effect of EECP on exercise-induced myocardial ischemia and anginal episodes. J Am Coll Cardiol. 1999; 33(7): 1833-1840, indexed in Pubmed: 10362।81.

15. Lawson WE, Hui JC, Lang G. Treatment benefit in the enhanced external counterpulsation consortium. Cardiology. 2000; 94(I): 31-35, doi: 10.1 I59/000007043, indexed in Pubmed: IIIIII 42.

16. Lawson WE, Hui JC, Cohn PF. Long-term prognosis of patients with angina treated with enhanced external counterpulsation: five-year follow-up study. Clin Cardiol. 2000; 23(4): 254-258, indexed in Pubmed: 10763072.

17. Urano $\mathrm{H}$, Ikeda $\mathrm{H}$, Ueno $\mathrm{T}$, et al. Enhanced external counterpulsation improves exercise tolerance, reduces exercise-induced myocardial ischemia and improves left ventricular diastolic filling in patients with coronary artery disease. J Am Coll Cardiol. 2001; 37(I): 93-99, indexed in Pubmed: III 53780.

18. Stys TP, Lawson WE, Hui JCK. Safety and effectiveness of enhanced external counterpulsation in improving angioplasty restenosis. proceedings of the 2 nd international congress on heart disease - new trends in research, diagnosis and treatment. International Academy of Cardiology. 2001; 24: 369-372.

19. Barsness G, Feldman AM, Holmes DR, et al. International EECP Patient Registry Investigators. The International EECP Patient Registry (IEPR): design, methods, baseline characteristics, and acute results. Clin Cardiol. 200 I; 24(6): 435-442, indexed in Pubmed: I I 403504.

20. Springer S, Fife A, Lawson W, et al. Psychosocial effects of enhanced external counterpulsation in the angina patient: a second study. Psychosomatics. 200 I; 42(2): 124-132, doi: 10.1 176/appi. psy.42.2.124, indexed in Pubmed: 11239125.

2I. Lakshmi MV, Kennard ED, Kelsey SF, et al. Relation of the pattern of diastolic augmentation during a course of enhanced external counterpulsation (EECP) to clinical benefit (from the International EECP Patient Registry [IEPR]). Am J Cardiol. 2002; 89(II): 1303-1305, indexed in Pubmed: I203।734.

22. Stys TP, Lawson WE, Hui JCK, et al. Effects of enhanced external counterpulsation on stress radionuclide coronary perfusion and exercise capacity in chronic stable angina pectoris. Am J Cardiol. 2002; 89(7): 822-824, indexed in Pubmed: II 909566.

23. Michaels $A D$, Accad $M$, Ports TA, et al. Left ventricular systolic unloading and augmentation of intracoronary pressure and Doppler flow during enhanced external counterpulsation. Circulation. 2002; 106(10): 1237-1242, indexed in Pubmed: 12208799.

24. Holubkov R, Kennard ED, Foris JM, et al. Comparison of patients undergoing enhanced external counterpulsation and percutaneous coronary intervention for stable angina pectoris. Am J Cardiol. 2002; 89(10): | | 82-1 | 86, indexed in Pubmed: | 2008 I 72.

25. Soran O, Fleishman B, Demarco T, et al. Enhanced external counterpulsation in patients with heart failure: a multicenter feasibility study. Congest Heart Fail. 2002; 8(4): 204-227, indexed in Pubmed: 12 447943.
26. Fitzgerald CP, Lawson WE, Hui JCK, et al. IEPR Investigators. Enhanced external counterpulsation as initial revascularization treatment for angina refractory to medical therapy. Cardiology. 2003; 100(3): 129-135, doi: 10.1159/000073930, indexed in Pubmed: |463| | 33 .

27. Bonetti P, Holmes D, Lerman A, et al. Enhanced external counterpulsation for ischemic heart disease. Journal of the American College of Cardiology. 2003; 4I(II): 1918-1925, doi: 10.1016/ s0735-1097(03)00428-5.

28. Shechter M, Matetzky S, Feinberg M, et al. External counterpulsation therapy improves endothelial function in patients with refractory angina pectoris. Journal of the American College of Cardiology. 2003; 4 I (6): 269, doi: I0. I0I6/s0735-1097(03)8226I-I.

29. Tartaglia J, Stenerson J, Charney R, et al. Exercise capability and myocardial perfusion in chronic angina patients treated with enhanced external counterpulsation. Clin Cardiol. 2003; 26(6): 287-290, indexed in Pubmed: 12839048.

30. Werner D, Marthol H, Brown CM, et al. Changes of cerebral blood flow velocities during enhanced external counterpulsation. Acta Neurol Scand. 2003; 107(6): 405-4II, indexed in Pubmed: 12757472.

31. Lawson WE, Kennard ED, Hui JCK, et al. IEPR Investigators. Analysis of baseline factors associated with reduction in chest pain in patients with angina pectoris treated by enhanced external counterpulsation. Am J Cardiol. 2003; 92(4): 439-443, indexed in Pubmed: |29|4875.

32. Linnemeier G, Rutter MK, Barsness G, et al. IEPR Investigators. Enhanced External Counterpulsation for the relief of angina in patients with diabetes: safety, efficacy and I-year clinical outcomes. Am Heart J. 2003; 146(3): 453-458, doi: 10.1016/ S0002-8703(03)0025I-5, indexed in Pubmed: 12947362.

33. Linnemeier G, Michaels A, Soran O, et al. Enhanced External Counterpulsation in the Management of Angina in the Elderly. The American Journal of Geriatric Cardiology. 2003; 12(2): 90-96, doi: 10.1 I I I/j. 1076-7460.2003.01749.x.

34. Bagger JP, Hall RJC, Koutroulis G, et al. Effect of enhanced external counterpulsation on dobutamine-induced left ventricular wall motion abnormalities in severe chronic angina pectoris. Am J Cardiol. 2004; 93(4): 465-467, doi: 10.1016/j.amjcard.2003.10.045, indexed in Pubmed: 14969625.

35. Michaels AD, Linnemeier G, Soran $O$, et al. Two-year outcomes after enhanced external counterpulsation for stable angina pectoris (from the International EECP Patient Registry [IEPR]). Am J Cardiol. 2004; 93(4): 46I-464, doi: 10.10I6/j. amjcard.2003.10.044, indexed in Pubmed: 14969624.

36. Lawson WE, Hui JCK, Barsness GW, et al. IEPR Investigators. Effectiveness of enhanced external counterpulsation in patients with left main disease and angina. Clin Cardiol. 2004; 27(8): 459-463, indexed in Pubmed: 15346843.

37. Masuda D, Fujita M, Nohara R, et al. Improvement of oxygen metabolism in ischemic myocardium as a result of enhanced external counterpulsation with heparin pretreatment for patients with stable angina. Heart Vessels. 2004; 19(2): 59-62, doi: 10.1007/s00380-003-0741-9, indexed in Pubmed: 15042388.

38. Henrikson CA, Chandra-Strobos N. Enhanced external counterpulsation therapy: significant clinical improvement without electrophysiologic remodeling. Ann Noninvasive Electrocardiol. 2004; 9(3): 265-269, doi: 10.11 II/j.1542-474X.2004.93570.x, indexed in Pubmed: 15245343. 
39. Taguchi I, Ogawa K, Kanaya T, et al. Effects of enhanced external counterpulsation on hemodynamics and its mechanism. Circ J. 2004; 68(II): 1030-1034, indexed in Pubmed: 15502384.

40. Lawson WE, Silver MA, Hui JCK, et al. Angina patients with diastolic versus systolic heart failure demonstrate comparable immediate and one-year benefit from enhanced external counterpulsation. J Card Fail. 2005; II(I): 61-66, indexed in Pubmed: 15704066.

4I. Michaels AD, Raisinghani $A$, Soran $O$, et al. The effects of enhanced external counterpulsation on myocardial perfusion in patients with stable angina: a multicenter radionuclide study. Am Heart J. 2005; 150(5): 1066-1073, doi: 10.1016/j. ahj.2005.01.054, indexed in Pubmed: 16291000.

42. Arora R, Chen HJ, Rabbani L. Effects of enhanced counterpulsation on vascular cell release of coagulation factors. Heart Lung. 2005; 34(4): 252-256, indexed in Pubmed: 16027645.

43. McCullough PA, Silver MA, Kennard ED, et al. IEPR Investigators. Impact of body mass index on outcomes of enhanced external counterpulsation therapy. Am Heart J. 2006; 15I(I): 139, doi: 10.1016/j.ahj.2005.10.003, indexed in Pubmed: 16368306.

44. Akhtar M, Wu GF, Du ZM, et al. Effect of external counterpulsation on plasma nitric oxide and endothelin-I levels. Am J Cardiol. 2006; 98(I): 28-30, doi: 10.1016/j.amjcard.2006.01.053, indexed in Pubmed: 16784915.

45. Soran O, Kennard ED, Kfoury AG, et al. IEPR Investigators. Two-year clinical outcomes after enhanced external counterpulsation (EECP) therapy in patients with refractory angina pectoris and left ventricular dysfunction (report from The International EECP Patient Registry). Am J Cardiol. 2006; 97(I): 17-20, doi: 10.1016/j.amjcard.2005.07. I22, indexed in Pubmed: 16377276.

46. Nichols WW, Estrada JC, Braith RW, et al. Enhanced external counterpulsation treatment improves arterial wall properties and wave reflection characteristics in patients with refractory angina. J Am Coll Cardiol. 2006; 48(6): 1208-1214, doi: 10.1016/j.jacc.2006.04.094, indexed in Pubmed: 16979007.

47. Lawson WE, Hui JCK, Kennard ED, et al. International Enhanced External Counterpulsation Patient Registry Investigators. Twoyear outcomes in patients with mild refractory angina treated with enhanced external counterpulsation. Clin Cardiol. 2006; 29(2): 69-73, indexed in Pubmed: 16506642.

48. Novo G, Bagger JP, Carta R, et al. Enhanced external counterpulsation for treatment of refractory angina pectoris. J Cardiovasc Med (Hagerstown). 2006; 7(5): 335-339, doi: 10.2459/0I. JCM.0000223255.24309.fa, indexed in Pubmed: I66454 I I.

49. Loh PH, Louis AA, Windram J, et al. The immediate and longterm outcome of enhanced external counterpulsation in treatment of chronic stable refractory angina. J Intern Med. 2006; 259(3): 276-284, doi: 10.1111/j.1365-2796.2005.01604.x, indexed in Pubmed: 16476105.

50. Arora RR, Bergmann S. Effects of enhanced external counterpulsation (EECP) on myocardial perfusion. Am J Ther. 2007; I4(6): 519-523, doi: 10.1097/01.mjt.0000249890.00290.30, indexed in Pubmed: 18090877.

51. Michaels AD, McCullough PA, Soran OZ, et al. Primer: practical approach to the selection of patients for and application of EECP. Nat Clin Pract Cardiovasc Med. 2006; 3(II): 623-632, doi: 10.1038/ncpcardio0691, indexed in Pubmed: 17063167.

52. McCullough PA, Henry TD, Kennard ED, et al. IEPR Investigators. Residual high-grade angina after enhanced external counterpulsation therapy. Cardiovasc Revasc Med. 2007; 8(3): 161-165, doi: 10.1016/j.carrev.2006.12.003, indexed in Pubmed: 17765644.

53. Yavari M, Montazeri HR. Effects of enhanced external counterpulsation on anginal symptoms and improvements in objective measures of myocardial ischaemia. Cardiovasc J Afr. 2007; 18(3): 154-156, indexed in Pubmed: 176| 2746.

54. Loh PH, Cleland JGF, Louis AA, et al. Enhanced external counterpulsation in the treatment of chronic refractory angina: a long-term follow-up outcome from the International Enhanced External Counterpulsation Patient Registry. Clin Cardiol. 2008; 31(4): 159-164, doi: 10.1002/clc.201 17, indexed in Pubmed: 18404725 .

55. Erdling A, Bondesson S, Pettersson T, et al. Enhanced external counter pulsation in treatment of refractory angina pectoris: two year outcome and baseline factors associated with treatment failure. BMC Cardiovasc Disord. 2008; 8: 39, doi: 10.1 I86/I47I-226I-8-39, indexed in Pubmed: 19094202.

56. Buschmann EE, Utz W, Pagonas N, et al. Arteriogenesis Network (Art. Net.). Improvement of fractional flow reserve and collateral flow by treatment with external counterpulsation (Art.Net.-2 Trial). Eur J Clin Invest. 2009; 39(I0): 866-875, doi: 10.1III/j.1365-2362.2009.02192.x, indexed in Pubmed: 19572918.

57. Esmaeilzadeh M, Khaledifar A, Maleki M, et al. Evaluation of left ventricular systolic and diastolic regional function after enhanced external counter pulsation therapy using strain rate imaging. Eur J Echocardiogr. 2009; 10(1): 120-126, doi: 10.1093/ejechocard/ jen I83, indexed in Pubmed: 18579500.

58. Soran O, Ikizler C, Sengül A, et al. Comparison of long term clinical outcomes, event free survival rates of patients undergoing enhanced external counterpulsation for coronary artery disease in the United States and Turkey. Turk Kardiyol Dern Ars. 2012; 40(4): 323-330, doi: 10.5543/tkda.2012.59/44, indexed in Pubmed: 22951848.

59. Eslamian F, Aslanabadi N, Mahmoudian B, et al. Therapeutic effects of Enhanced External Counter Pulsation (EECP) on clinical symptoms, echocardiographic measurements, perfusion scan parameters and exercise tolerance test in coronary artery disease patients with refractory angina. International Journal of Medical Science and Public Health. 2013; 2(2): 187, doi: 10.5455/ijmsph.2013.2.179-187.

60. Bozorgi A, Mehrabi Nasab E, Sardari A, et al. Effect of Enhanced External Counterpulsation (EECP) on Exercise Time Duration and Functional Capacity in Patients with Refractory Angina Pectoris. J Tehran Heart Cent. 2014; 9(I): 33-37, indexed in Pubmed: 25561968.

6I. Beck DT, Martin JS, Casey DP, et al. Enhanced external counterpulsation improves endothelial function and exercise capacity in patients with ischaemic left ventricular dysfunction. Clin Exp Pharmacol Physiol. 2014; 4I(9): 628-636, doi: 10.1 III/14401681.12263, indexed in Pubmed: 24862172.

62. Tabary S, Yousefnejad K. Assessment the clinical and paraclinical effects of enhanced external counter pulsation therapy in patients with coronary artery disease. Int J Med Invest. 2015; 4(2): 245-248.

63. Subramanian R. Effect of EECP treatment on aortic blood pressure, arterial stiffness and $E F$ in patients with $C A D$. Journal of Clinical and Diagnostic Research. 2016; 10(10): 30-34. 
64. Beck DT, Casey DP, Martin JS, et al. Enhanced external counterpulsation reduces indices of central blood pressure and myocardial oxygen demand in patients with left ventricular dysfunction. Clin Exp Pharmacol Physiol. 2015; 42(4): 315-320, doi: 10.1 I I I/I440-1681.12367, indexed in Pubmed: 25676084.

65. Arora RR, Chou TM, Jain D, et al. Effects of enhanced external counterpulsation on Health-Related Quality of Life continue 12 months after treatment: a substudy of the Multicenter Study of Enhanced External Counterpulsation. J Investig Med. 2002; 50(I): 25-32, doi: 10.2310/6650.2002.33514, indexed in Pubmed: $1|8| 3825$.

66. Kumar A, Aronow WS, Vadnerkar A, et al. Effect of enhanced external counterpulsation on clinical symptoms, quality of life, 6-minute walking distance, and echocardiographic measurements of left ventricular systolic and diastolic function after 35 days of treatment and at $\mathrm{I}$-year follow up in 47 patients with chronic refractory angina pectoris. Am J Ther. 2009; 16(2): I 16-I 18, doi: 10.1097/MJT.0b013e3 1814db0ba, indexed in Pubmed: 19300038.

67. Wu E, Mårtensson J, Broström A. Enhanced external counterpulsation in patients with refractory angina pectoris: a pilot study with six months follow-up regarding physical capacity and health-related quality of life. Eur J Cardiovasc Nurs. 2013; 12(5): 437-445, doi: 10.1 I77//4745 /5 | |2468067, indexed in Pubmed: 2326327I.

68. Ziaeirad M, Ziaei GR, Sadeghi N, et al. The effects of enhanced external counterpulsation on health-related quality of life in patients with angina pectoris. Iran J Nurs Midwifery Res. 2012; 17(I): 4I-46, indexed in Pubmed: 23493242.

69. Jorgensen MT, May O. Improvement of angina, quality of life, and working capacity after enhanced external counterpulsation. UgeskrLaeger. 2013; 175(3): I14-16.

70. May O, Lynggaard V, Mortensen JCA, et al. Enhanced external counterpulsation - effect on angina pectoris, QoL and exercise capacity after I year. Scand Cardiovasc J. 2015; 49(I): I-6, doi: 10.3109/14017431.2014.994028, indexed in Pubmed: 25471629.

71. Shakouri SK, Razavi Z, Eslamian F, et al. Effect of Enhanced External Counterpulsation and Cardiac Rehabilitation on Quality of Life, Plasma Nitric Oxide, Endothelin I and High Sensitive CRP in Patients With Coronary Artery Disease: A Pilot Study. Ann Rehabil Med. 2015; 39(2): 191-198, doi: 10.5535/ arm.2015.39.2.191, indexed in Pubmed: 259324I5. 